\title{
The Incidence and Cost of Job Loss in the Ukrainian Labor Market ${ }^{1}$
}

\author{
Hartmut Lehmann ${ }^{2}$ \\ Department of Economics, University of Bologna, Italy \\ IZA, Bonn, Germany \\ Norberto Pignatti \\ Department of Economics, University of Bologna, Italy \\ IZA, Bonn, Germany \\ Jonathan Wadsworth \\ Royal Holloway College, University of London, Egham, U.K. \\ Centre for Economic Performance, London School of Economics, U.K. \\ IZA, Bonn, Germany
}

This version: September 2005

\begin{abstract}
We examine the effects of economic transition on the pattern and costs of worker displacement in Ukraine, using the Ukrainian Longitudinal Monitoring Survey (ULMS) for the years 1992 to 2002. Displacement rates in the Ukrainian labor market average between 3.4 and 4.8 percent of employment, roughly in line with levels typically observed in several Western economies, but considerably larger than in Russia. The characteristics of displaced workers are similar to those displaced in the West, in so far as displacement is concentrated on the less skilled. Around one third of displaced workers find re-employment immediately while the majority continues into long-term non-employment. The wage costs of displacement for the sub-sample of displaced workers do not seem to be large. The main cost for displaced workers in Ukraine consists in the extremely long non-employment spell that the average worker experiences after layoff.
\end{abstract}

JEL Classification: J64; J65; P50

Key words: Displaced workers; Labor markets in transition; Ukraine

\footnotetext{
${ }^{1}$ The authors are grateful to Andrew Newell and participants of the IZA-EBRD conference on "Labor Market Dynamics, the Role of Institutions and Internal Labor Markets in Transition and Emerging Market Economies" in May 2005 in Bologna for valuable comments and suggestions. This paper is part of the CERT-RWI project "Analysis of Labor Market Adjustment with Large Micro Data Sets." Financial support from EROC at NAUKMA, Kiev and the Upjohn Institute is also gratefully acknowledged. This study utilizes the ULMS data set, a project initiated within the IZA-program "Labor Markets in Emerging and Transition Economies." The project is financially supported by a consortium led by IZA, Bonn. The other permanent members of the consortium are CERT, Heriot-Watt University Edinburgh, EERC-Ukraine and RWI-Essen.
}

${ }^{2}$ Corresponding author; Department of Economics, Strada Maggiore 45, 40125 Bologna.

Email:lehmann@spbo.unibo.it 


\section{Introduction}

The labor markets of the successor states of the Former Soviet Union (FSU), excluding the Baltic states, are often thought to display different adjustment patterns after the initial transition shock than the labor markets of Central Europe. Dramatically falling real wages, wage arrears and unpaid forced leave for a large fraction of the workforce were the most important mechanisms, with which enterprises responded to a collapse in the demand for their products. Since these mechanisms effectively lowered the cost of labor, a moderate rate of labor shedding in Russia and other countries of the Common Wealth of Independent States $(\mathrm{CIS})^{3}$ was observed over an extended period. ${ }^{4}$ Anecdotal evidence from the Ukraine suggests that these adjustment mechanisms were more prevalent even than in Russia for most of the nineties. $^{5} \quad$ As a consequence, Konings, Kupets, and Lehmann (2003) find a moderate aggregate rate of labor shedding in the nineties in the Ukrainian labor market. However, these authors as well as Brown and Earle (2003) also establish that relentless gross job and worker reallocation was behind the small net fall in employment, a pattern which has continued after the Ukrainian economy began growing again in 2000. In such an environment, job displacement might be important.

Despite the extensive literature that examines large-scale privatization and structural reforms in developing and transition economies, e.g. Djankow and Murell (2002), little has been written about job displacement in these countries. Kletzer (1998) and Kuhn (2002) summarize the large empirical Western literature on job displacement which establishes the extent, incidence, and costs of displacement. These issues are particularly pertinent for transition economies in which institutional structures are often evolving rapidly alongside mass privatization, large scale restructuring, and the reallocation of labor.

The Western literature on displacement focuses on seniority, firm-specific human capital premia, and union wage premia as the main reasons that displaced workers experience substantial earnings losses. For Europe, Kuhn (2002) shows that the cost of job loss is lower than in the United States or in Britain. This result appears to be driven by institutional features in Europe that cushion unemployment income, job search, and pay in return jobs. However, we may not observe similar features in a transition economy, because institutional factors are less likely to attenuate the costs of job loss (Lehmann, Philips, and Wadsworth, 2005).

\footnotetext{
${ }^{3}$ The states of the FSU without the Baltic States

${ }^{4}$ For Russia, see for example, Lehmann, Wadsworth, and Acquisti (1999), Earle and Sabirianova (2002), and Earle and Lehmann (2002).

${ }^{5}$ Standing and Zsoldos (2001) provide some hard evidence for Ukrainian industry on this point.
} 
Little empirical evidence exists to distinguish among these possible outcomes in transition economies. Orazem, Vodopivec and $\mathrm{Wu}$ (2004), examine official administrative data on workers displaced in Slovenia between 1987 and 1993. They find substantial longterm unemployment among displaced workers but real wage growth, on average, for those who find new work. However, large real wage cuts are taken by workers with 25 or more years of work experience. For Estonia, Lehmann, Philips, and Wadsworth (2005) show that displacement rates were very large compared to Western countries in the early stage of transition but fell back toward average Western levels in the later, mature period of transition. They also find that, like in the West, less-skilled workers and those workers with short job tenure experience displacement disproportionately. The main cost of being displaced from a job is the income loss due to non-employment rather than a wage penalty for those who return to work. For Russia, Earle and Sabiarianova Peter (2004) maintain that the incidence of displacement is extremely low. However, their evidence is based on the responses of managers who might have an incentive to understate the real level of displacement. While there are also problems with worker survey data (see e.g. Kuhn, 2002), our nationally representative data set allows us for the first time to obtain a general estimate of the incidence of displacement in a labor market of the CIS.

With more rapid restructuring and labor reallocation than in the West, a transition economy might create a sufficiently dynamic environment in which individuals could move quickly between jobs and productivity levels in the new or restructured sectors might offer relatively good wage prospects. In this case, the costs of job loss would be small. In the Ukraine, a more dynamic environment has existed since the period of rapid economic growth began in the 2000. Conversely, the potential costs of job loss could be high because unemployment benefit payments, which despite being earnings-related, are low and strict eligibility criteria exclude many of the unemployed, (Lehmann, Kupets, and Pignatti, 2005). As a consequence, most displaced individuals excluded from benefit would have to try to return to work quickly. If high search costs then compromise efficient matching this could increase the intensive cost of displacement by raising the likelihood of wage penalties associated with displacement. Other potential costs of job loss stem from differences in wages between old and new jobs. For a majority of Ukrainian workers, wages after transition were still tied to Soviet wage grids. This process recognized seniority so that higher tenured workers could expect to receive higher wages. If such workers lose their jobs, the skills acquired under the old regime may not be in demand in a restructuring, transition economy, as Lehmann and Wadsworth (2000) argue. Hence, older workers are likely to suffer most from 
displacement. Lehmann, Kupets, and Pignatti (2005) document large job creation rates in the new private sector in Ukraine. If these new jobs are high productivity jobs as the evidence in their paper seems to suggest, displaced workers could obtain wages in their new job that would be comparable to, or higher than those in the previous job. Ukrainian employment protection legislation is comparable to that in many West European countries so that, other things equal, the incidence of job loss should be broadly comparable. However, compliance with legal provisions has been particularly problematic. Trade unions play a minor role in the Ukrainian wage determination process, like in most transition economies.

With no clear theoretical guidance as to the likely wage change following displacement and eventual re-employment in a transition economy, empirical evidence is required. This will have important policy implications, in particular for Ukraine where the economy will still need to undergo a major restructuring effort. If displaced workers can find new work relatively quickly and receive wages that exceed those in their former job, policymakers will have less concern over job displacement than in a situation characterized by long-term unemployment and a future of low paying jobs.

In what follows, we analyze changes in the pattern of displacement for two distinct periods of transition, the years 1992 to 1997 and 1998 to 2002. The first period is characterized by a deep depression accompanied by a prolonged episode of hyperinflation, and subsequently the implementation of restrictive stabilization policies that result in a stable currency by 1997. By 1998, the "transition cycle" had reached a trough, with GDP growth in 1999 and accelerated growth since the year 2000. For the two periods, we differentiate the characteristics of displaced workers from other workers who experience joblessness and from those workers who manage to avoid non-employment. We investigate whether displaced workers experience longer or shorter non-employment spells and whether systematic differences arise between the two groups of job separations. For the second period, when inflation and the currency had stabilized, we also analyze earnings changes associated with displacement to establish the pecuniary costs of job displacement.

The next section outlines the Ukrainian Longitudinal Monitoring Survey (ULMS) data used in our study and section 3 discusses the general patterns of displacement and the incidence of job loss in Ukraine. Sections 4 and 5 look at the two main components of the costs of job loss, i.e. the duration of non-employment and the potential income losses of displaced workers who find a new job. Section 6 offers some conclusions on the overall cost of displacement and on social policy. 


\section{The Data}

Our principal source of information is the ULMS, a nationally representative survey, similar to the Russian Longitudinal Monitoring Survey (RLMS), of around 4,000 households and approximately 8,500 individuals, undertaken for the first time in the spring of 2003. A household questionnaire contains items on the demographic structure of the household, its income and expenditure patterns together with living conditions. A more detailed description of the genesis and the content of the data set can be found in Lehmann and Haisken-DeNew (2005). The core of the survey is the individual questionnaire, which elicits detailed information concerning the labor market experience of Ukrainian workers. There is an extensive retrospective section, which tracks workers' labor market involvement at specific past points in time (December 1986 and December 1991) and which allows a complete reconstruction of workers' labor market histories between January 1998 and the date of the interview. The responses allow us to estimate annual separation, displacement and quit rates along with the duration (in months) of any non-employment spell resulting from a separation. The data also identify job moves that involve no intervening spell of non-employment following a separation. These job-to-job moves are given the value 1 (month) and the value of one is added to all other monthly duration spells to facilitate the estimation process. To analyze hazard rates from non-employment, we use discrete time hazard estimation methods because the spell data are measured in monthly intervals. Sample size limitations prevent us from distinguishing between those displaced workers who entered unemployment and those who became economically inactive. We therefore count any jobless spell as a period of nonemployment. Often the same non-employment spell involves periods of both unemployment and economic inactivity and the degree of search activity which conditions classification into these states might be considered endogenous to the rate of job offer arrival.

Table A1 in the appendix demonstrates how we construct a measure of displaced workers that mirrors the one used in the Western literature in which displaced workers are typically classified as those who are separated involuntarily from their jobs by mass layoff or plant closure. The ULMS allows us to distinguish between job loss because of plant closure, firm reorganization, bankruptcy, privatization, dismissal initiated by employer, and personnel reduction (items 1 through 6 in Table A1). Our measure of displacement is conservative in that we exclude separations due to end of contract or probation time (items 7 and 8). These latter two reasons and items 9 through 24 then constitute job quits, so, the estimated displacement rates are lower bounds. 
We can calculate job tenure and work experience over this sample period, but the data do not allow us to calculate total work experience since for those who began work before 1998 . Therefore, we use age as a proxy for total work experience. For the period 1998 to 2003, workers leaving or losing a job are asked to give their final salary measured as gross monthly wages in Hryvnia. If workers are paid in another currency (e.g. dollars or rubles), they are asked to state the currency. Workers starting a new job are asked to give their starting salary. All those with a job are asked to give their wages in December of each year. We exclude individuals who work abroad. Due to concerns over the reliability of retrospective data in periods of hyperinflation and also when the carbovanets was the national currency, we exclude the years before 1998 from our wage analysis. Since the official retirement age is 60 for men and 55 for women, but many work beyond these age limits, we construct measures of separations, displacements and quits based on two age intervals in the given year, 15 to 59 and 15-72. However, as our measures are not very sensitive to the choice of age interval, we present in the main text only figures associated with the statutory retirement age.

\section{The Incidence of Displacement}

The top panel of Figure 1 and the last rows of Tables 1 and A2 outline the pattern of annual job displacement rates in Ukraine in the year immediately after independence and the years 1998 to 2002 when the economy was coming out of a deep and prolonged recession. Displacement is relatively low in 1992 but rises to between four and five per cent in the years 1998 to 2002 . These latter figures are broadly comparable with those from the Western literature; for example, U.S., Dutch, German and British displacement rates average between 3 to 6 percent of the workforce in a year (Kuhn, 2002). In the mature stage of transition, Estonia had a displacement of 6\% (Lehmann, Philips, and Wadsworth, 2005). Hence, Ukraine has displacement rates only slightly lower than one of the fast reformers among the transition economies. As the central panel of Figure 1 shows, redundancies rather than plant closures account for the majority of displacement. Plant closures reach a peak, at slightly more than one fifth of all displacements, in 1998. Bankruptcies, on the other hand, are the least important reason for displacement.

The incidence of quits is much larger than that of displacements, accounting for around two thirds of separations. Quits grew between 1992 and 2002, reaching 14\% of employment in the latter year. The bottom panel of Figure 1 shows that voluntary job separations and retirements are responsible for the majority of quits throughout the period. 
Table 1 shows that men were less likely to experience displacement between 1998 and 2000 but more likely to do so in the last two years of the sample period. Since 1999, Ukrainian workers have experienced less displacement than the rates for ethnic Russian workers, which might be related to the larger employment share of ethnic Russians in industries most affected by downsizing. Displacement rates are relatively uniform across age groups, while displacement does fall disproportionately on less-educated individuals. For most of the period, less-skilled workers experience more displacement. The incidence of displacement by job tenure shows a U-shaped relationship in 2002, implying that individuals relatively new in their job and those with very long tenure are mostly affected by involuntary separations. This pattern cannot be observed for earlier years in the data. The western part of Ukraine has far lower displacement rates than the rest of the country throughout the entire period.

Job loss is much lower in the sector "education, health, and social work" throughout the period, while displacement in the wholesale and retail trade, hotel and finance sectors remains consistently high. The other two industries where displacement is comparatively high in the examined years are manufacturing and mining and construction. As far as ownership is concerned, it is striking that new private firms have substantially larger displacement rates than both state-owned and privatized firms, hinting possibly at learning effects. It is noteworthy that in the early years of the period, worker displacement in the new private sector is caused equally by firm exit as well as redundancies while the latter dominates in 2002 . So, in the early years many of the newly created firms turned out to be non-viable while in 2002 many of the newly created firms seem to survive but decrease their workforce.

All survey data on displacement are plagued to some degree by selection bias. If workers have rational expectations about the economic viability of their firm, those workers with good prospects in the labor market may quit the firm before the firm is closed down or before mass layoffs occur. Hence, workers with worse characteristics remain. In restructuring firms that do not close down but initiate mass layoffs, the better-quality workers may stay with the firm because of potential post-restructuring productivity gains that generate high wage growth. ${ }^{6}$ Whether selection problems related to mass layoffs and plant closure are particularly strong in transition economies is a contentious issue. Potential failure or poor performance of firms may be easier to perceive in a transition economy and, as a result, good workers would be more likely to leave the firm before closure or large-scale labor shedding. Conversely, good

\footnotetext{
${ }^{6}$ Pfann (2001) finds workers with higher expected productivity growth are the "better quality" workers retained by the firm. In a transition context, such workers might want to stay in restructuring firms.
} 
workers may have more reason to retain their old job in restructuring firms because of the prospect of higher future rewards after restructuring. Workers may also keep their jobs because of greater uncertainty in a rapidly changing transition labor market or because of poor outside options, which both characterize the situation in the Ukrainian labor market throughout the sample period. Since we are unable to discern which of these scenarios prevails, we allow for the possibility of unobserved heterogeneity in the estimates of jobless duration and the cost of job loss.

If an exogenous shock affects all sectors equally, displaced workers would not be different from other workers. However, Tables 1 and A2 suggest that displacement is nonrandom across observable characteristics. Multinomial logit estimates of relative displacement probabilities shown in Table 2 for the periods 1992 to 1997 and 1998 to 2002 confirm this. The marginal effects are not directly comparable across the two periods, since the construction of the data allows the estimation of annual probabilities only for the latter period, while we can estimate the probability of being displaced or of quitting at any point in time in the interval 1992 to 1997.

For the earlier period, female workers have a probability of being displaced that is 2.3 percentage points higher throughout the early period and 0.5 percentage points in the years 1998 to 2002. Once we control for industry, there is no longer a difference in the probability of being displaced between Ukrainian and Russian workers although the propensity to quit is lower among Ukrainians in the years 1992 to 1997. Also, job losers have a relatively uniform age profile while job quitters are concentrated in the youngest and oldest age groups in the latter period and among the oldest age group in the earlier period. Educational background, on the other hand does not seem to matter as far as job loss is concerned while between 1992 and 1997 the least educated workers have the highest quit rates. These rates are also not affected by educational attainment in the interval 1998 to 2002. In general, low tenure workers are more likely to quit. In the early period, displacement was particularly high for medium term tenure, while essentially unaffected by tenure in the years 1998 to 2002.

The multinomial regressions only partially confirm the effect of ownership type on displacement given by the simple cross tabulations, since workers in state-owned firms have the same incidence of displacement than workers in newly established firms. On the other hand, workers in privatized firms are less affected by displacement than their counterparts working in firms with other ownership structures. 
Workers in manufacturing, construction and retail trade and hotel services seem particularly hard hit by displacement throughout the years 1992 to 2002. In contrast, educators, health and social workers as well as workers in transport seem less affected by displacement, with workers in education, health and social work having a lower probability of 3 points per annum in the second time interval. One plausible implication of these findings is that the latter industry did not undergo any major restructuring effort throughout the period. Firm size is not an important predictor as far as both displacement and voluntary quitting are concerned. In contrast, and this is the most striking results of the multinomial regressions, throughout the entire sample period, workers in Kyiv city have a higher incidence of being displaced and much larger propensities to quit than workers in other parts of the country.

These results make clear that the high raw displacement rates of workers in the new private sector are at least partially linked to a composition rather than an ownership effect. Calculations, which are not reported here, show that about two thirds of all employment in new private firms is concentrated in the sectors industry, construction and wholesale/ retail trade/hotels and restaurants and that a large part of employment in new private firms is located in Kyiv city.

In summary, throughout the period, industry affiliation, job characteristics, and geographic location rather than personal characteristics were the main determinants of closures and permanent layoffs. In the next two sections, we outline the possible costs of job loss in Ukraine and investigate to what extent these costs have changed over time.

\section{The Cost of Job Displacement in Ukraine: Duration of Joblessness}

Job loss involves both a risk of non-employment and a possibility of lower wages for those workers who find new employment. We first report the cumulative return rates to employment, conditional on non-employment duration, of displaced workers and compare these to return rates of quits for the two periods. ${ }^{7}$ The rates in Table 3 are based on the complement of the Kaplan-Meier estimator of survivor functions (Smith, 2002) in nonemployment. In the years 1992 to 1997 only a small fraction of both displaced workers and workers who separated voluntarily get back into employment immediately through a job-tojob move. However, most of the 43 percent of the displaced who return to work within a year do so during the first three months. It is striking that less than half of all workers who

\footnotetext{
${ }^{7}$ We now remove early retirements from the job quit sample because their return to work probabilities are very low.
} 
separated from a job find reemployment after one year, leading to a large incidence of longterm non-employment among these workers.

During the recovery period between 1998 and 2002, around about one-third of workers returned to work through a job-to-job move after having been displaced, while only an additional 13 percentage points return to work within a year. Kuhn (2002) finds that twothirds of displaced workers in the United States are re-employed within six months. In Britain, half of the displaced workers return within two months. By western standards, Ukrainian displaced workers have low return rates. While a minority of workers find reemployment after a very brief spell of non-employment, a majority of workers lingers on in non-employment for a very long time. In general, workers who separated voluntarily have return rates that are roughly 10 percentage points higher at each spell length. Finally, the median duration of completed spells, which stays at 1 month for the latter period, also demonstrates that in the interval of 1998 to 2002 most who return to work do so nearly immediately after having separated from their previous job. The Ukrainian hazards are similar to those found in Estonia by Lehmann, Philips, and Wadsworth, (2005) and could therefore suggest that these return rate patterns could well characterize the experience of displaced workers under transition.

These results have two clear consequences. First, the Ukrainian labor market cannot be characterized as dynamic as implied in the study by Boeri and Terrell (2002). Second, one possible source of adverse selection in analyzing a pool of displaced workers may be of some concern for our sample of Ukrainian workers.

The Kaplan-Meier estimates of these rates over the sample period are given in Figure 2 confirm the findings of Table $3 .^{8}$ In the early years of the sample, hazard rates into employment are high during the first two months of a jobless spell. Thereafter, the hazard rates fall dramatically and stay uniformly low. In the later years of the sample, the hazard rates fall precipitously after the first month. The hazard rates for displaced workers are generally not statistically different from those of quits at spell lengths other than job-to-job moves.

These data suggest that around a third of all displaced workers find a new job relatively rapidly, while the other two thirds have difficulty moving back into work. Unemployment benefits and related welfare payments are low and often not paid in most

\footnotetext{
${ }^{8}$ The standard errors for these hazard rate estimates are in the order of 0.001 to 0.002 .
} 
regions of Ukraine. 9 Hence, any incentive problems associated with the benefit system are unlikely to explain this flat hazard rate after two months. Figure 2 shows no obvious spikes in the hazard rates around the time of benefit exhaustion, which for the maximum benefit is given after 12 months of unemployment. Rather, a third of the displaced workers with presumably appropriate characteristics are re-employed rapidly, while those unable to move into employment quickly incur large income losses. However, any implied income losses would be exaggerated if individuals work in the informal sector, which is estimated to be substantial in Ukraine. ${ }^{10}$

We model the hazard rates and the determinants parametrically using the complementary log-log model suggested in the literature, e.g. Jenkins (2003), when the underlying spell data are intrinsically continuous but the researcher observes only that the spell length falls within a discrete interval. In this case, the discrete-time hazard rate for individual $i$ at time $t$ endowed with a set of characteristics $X$, can be written as:

$\mathrm{h}_{\mathrm{i}}(\mathrm{j}, X)=1-\exp \left[\exp \left(\beta^{\prime} X+\gamma_{\mathrm{t}}\right)\right]$, where $\gamma_{\mathrm{t}}$ summarizes the pattern of duration dependence in the discrete-time hazard function. We model this duration dependence flexibly by introducing a piecewise constant, which in practice amounts to the addition of 3 dummy variables for the first 6 months of any jobless spell. ${ }^{11}$

The $X$ vector contains a set of individual characteristics that might be expected to influence the opportunity cost of not working in addition to a set of characteristics of the job from which the worker was displaced. The presence of unobserved individual specific characteristics that affect the return to employment would, of course, lead to biased estimates of the parameters of these exit rates. If the unobserved heterogeneity, $v$, is distributed independently of any observed $X$ variable, it can be integrated out by assuming a functional form that can be summarized in a few parameters. For this, we use a Gamma-distributed parametric function and allow for right censoring of any spells. To focus on the comparative aspects of displacement, we exclude those who leave a job for retirement from the sample of quits. For the two periods, we pool the non-employment spell data and estimate discretetime, proportional hazard functions for displaced workers and quits in Table 4. We also present additional hazard rate estimates, ignoring unobserved heterogeneity, in Table A3 in

\footnotetext{
${ }^{9}$ The Ukrainian unemployment benefit system is earnings-related; in Kyiv, where average wages are much higher that in the rest of the country, benefit payments can on average be quite generous. Such generosity is absent in the rest of the country.

${ }^{10}$ Lehmann, Kupets, and Pignatti (2005) estimate that between 27 and 33 percent of the unemployed are engaged in informal activities in the latter sample period.

${ }^{11}$ Additional dummy variables for the periods beyond 6 months were not significant in both time periods.
} 
the appendix. With the unobserved heterogeneity parameters insignificant in all regressions of Table 4, the results in Tables 4 and A3 are broadly comparable.

In contrast to the findings in Table 2 concerning the incidence of job loss, the estimates in Table 4 suggest that not only job attributes of previous employment but also individual characteristics are important determinants of the return to work hazard rate. Female workers have substantially lower return rates. Workers with university education have substantially higher hazard rates throughout the decade, regardless of whether they are displaced or quit. It is noteworthy that ethnicity has no explanatory power with respect to the hazard from non-employment.

Importantly, job tenure does influence the hazard rate in the earlier period, as displaced workers having job tenure of medium length in the old job return to work earlier. This tenure effect is no longer present in the second period. Those with previous employment in manufacturing, retail and education and health return to work earlier than those who worked in agriculture in the latter period. It is striking that in both periods regional location does not seem to affect outflows from non-employment whether we deal with displaced workers or those who quit. The duration dependence parameters confirm the pattern of the Kaplan-Meier estimates; the probability of finding work within the first three months of any jobless spell is high but the hazard rate is low thereafter. In the latter period, this return to work probability is significantly higher only within the first month of any jobless spell.

\section{The Earnings Cost of Job Displacement in Ukraine}

We begin by examining re-entry wages for displaced workers. Table 5 gives estimates of the determinants of the log of the new real wage and of the change in the log of real wages for displaced workers who find a new full-time job conditional on observed individual characteristics and the characteristics of the old job. ${ }^{12}$ We obtain wages from the job history data in the ULMS from the December of each year from 1997 to 2002 . Since we have shown that less than one third of displaced workers return to work during the sample interval, Ordinary Least Squares (OLS) estimates of these wage determinants based only on the subsample of returnees may be subject to selectivity bias. The effects of the independent variables on the wages of those not yet re-employed may differ from the effects on those who return to work. To address this issue, we contrast OLS estimates with those based on the maximum likelihood estimation of the selection bias correction model of Heckman (1979). The selection equations and sample means of the covariates for the two sub-samples of 
displaced returnees and non-returnees are given in Table A4 of the Appendix. The selection equations are identified by controls for the number of children, which are also used by Podgursky and Swaim (1987), marital status, and reliance on land to produce food in the year prior to displacement. These variables are used also in Table 4 and are assumed to affect both the opportunity cost and the probability of return to work, but not the wage offered.

Column 1 of Table 4 indicates that wage premia were paid to men, workers with higher vocational and university education, those with jobs in the capital and workers in large establishments. In the Western literature, industry-specific human capital is considered to be important for maintaining previous wage levels in new jobs (Neal, 1995). Hence, changing industry should result in a wage penalty. This hypothesis is clearly supported by the data. In addition, a significant wage penalty accrues to those who were out of work for more than one month. On the other hand, the ownership type of the firm in the old job does not appear to affect wages on return to work. There is however a significant premium for those workers who changed regions after displacement, probably reflecting higher wages on offer in the capital city. Note that there is no reward to seniority (age) in the new jobs filled by displaced workers. A wage penalty for previously working in agriculture and a premium for having worked in firms with more than 100 employees are the only additional noteworthy results in column 1 .

In contrast to Lehmann, Philips, and Wadsworth (2005), using Estonia data, but in line with Orazem et al. (2004) for Slovenia, the selection terms are positive. ${ }^{13}$ This indicates that workers who could potentially command higher wages are more likely to be found back at work and may point to the nature of job creation at this stage of the transition process in the Ukraine. The coefficient estimates of the Heckman correction model in column 2 are however broadly similar to the OLS estimates. In columns 3 and 4 we add the last wage observed in the job before displacement to the vector of controls as an additional control for individual heterogeneity and also to investigate whether regression to the mean in wages occurs among displaced workers. ${ }^{14}$ The coefficients on the last wage are highly significant and all coefficients are less than one, indicating that workers who were relatively highly paid before displacement experience higher proportionate wage losses if they return to work. The addition

\footnotetext{
12 Results for wage changes of those who quit and found a new job are available on request.

${ }^{13}$ The selection terms are given by the coefficients on Lambda. These coefficients represent the correlation coefficient between the error term of the wage equation and the error term of the selection equation. Verbeek (2000) provides a lucid discussion of the basic Heckman selection model.

${ }_{14}$ See for example Podgursky and Swaim (1987). If $\mathrm{LnW}_{\mathrm{ti}}=\mathrm{b}_{1} \mathrm{LnW}_{\mathrm{t}-1 \mathrm{i}}+\mathrm{b}_{2} \mathrm{Z}_{\mathrm{t}-1 \mathrm{i}}$, then the proportional change in wages due to displacement, $\mathrm{Ln}\left(\mathrm{W}_{\mathrm{ti}} / \mathrm{W}_{\mathrm{t}-1 \mathrm{i}}\right)=\left(\mathrm{b}_{1}-1\right) \mathrm{LnW}_{\mathrm{t}-1 \mathrm{i}}+\mathrm{b}_{2} \mathrm{Z}_{\mathrm{t}-1 \mathrm{i}}$. . Hence the coefficient on the last wage measures the extent to which future wage changes depend on past earnings.
} 
of the selection controls also raises the significance of the job tenure variables which suggest that high tenured workers suffer greater relative wage loss on a return to work.

When the last wage is included, the size of many of the individual and job coefficients are reduced because the effect of many of these variables is absorbed by previous earnings. However, the significance of the effects is unaltered. In columns 5 and 6, we examine the change in wages by imposing a coefficient of 1 on lagged wages and removing any unobserved individual fixed effects that may determine wage levels. There are significant effects of education, firm size, tenure, industry change and change of region on wage changes.

The results of Table 5 do not capture any earnings loss due to displacement. To evaluate whether wage loss is a significant aspect of displacement in the Ukraine, we must compare the wage in the new job with its counterfactual, i.e. the wage that would have prevailed if the worker had not been displaced and had remained in the original job. Therefore, we next construct difference-in-difference estimators, comparing the 2 year change in the log of monthly wages of workers who those who remain in work with the two-year change for displaced workers. The class of these estimators can be written as follows:

$$
\begin{aligned}
& \left\{E\left(w_{2} \mid X ; d=1\right)-E\left(w_{1} \mid X ; d=1\right)\right\}-\left\{E\left(w_{2} \mid X ; d=0\right)-E\left(w_{1} \mid X ; d=0\right)\right\} \\
& E\left(w_{2} \mid X ; d=1\right)-E\left(w_{2} \mid X ; d=0\right)+E\left(w_{1} \mid X ; d=0\right)-E\left(w_{1} \mid X ; d=1\right)
\end{aligned}
$$

where $\mathrm{w}_{1}$ and $\mathrm{w}_{2}$ are wages in the first and second period, and $X$ is a vector of conditioning variables. The variable $d$ takes a value of one in the treatment case, i.e., displacement and zero in the no-treatment case, i.e., the worker remains in the job. If $\mathrm{E}\left(\mathrm{w}_{1} \mid X ; d=0\right)=\mathrm{E}\left(\mathrm{w}_{1} \mid X ; d=1\right)$ in equation (2), i.e. if the conditional expectation of the wage before displacement were the same for displaced workers and those who remain, the effect of displacement on earnings would be given by the first two terms in equation (2). Therefore, the earnings loss would be identified by this difference-in-differences estimator. ${ }^{15}$

The sample of displaced workers with wages observed before and after displacement is rather small. Of the 1362 workers in our sample who were displaced sometime between December 1997 and December 2002, 262 are observed with wages in the December before and the December after displacement, (reflecting the low rates of return to employment of displaced workers observed in Table 5), and 168 are observed with wages in all 6 consecutive years.

\footnotetext{
${ }^{15}$ See Manski (1995) for a lucid discussion of identification.
} 
Table 6 outlines the results of the difference-in-differences exercise. The results in Table 5 suggest that unobservable factors may determine re-entry wages for displaced workers. This indicates a classic self-selection problem and $\mathrm{E}\left(\mathrm{w}_{2} \mid X ; d=1\right)$ could be biased. However, differencing the wage removes any unobservable fixed effects that influence wage levels, although any selection effects on wage changes remain. If the latter are important, our results apply only to the subset of displaced workers who return to work. Given these caveats, the results of Table 6 suggest that there is no short-run wage penalty to displacement. The difference-in-differences estimator (the interaction of the displacement dummy and the second period time dummy) is always insignificantly different from zero. ${ }^{16}$ When the displacement dummy is replaced by the spell length in panel B, the difference in difference estimates of the effects of spell length are negative but not statistically significant.

To measure the longer-term wage costs of displacement we follow the standard methodology in the literature (for example Jacobsen et al. (1993) or Stevens (1997)) comparing wages of displaced workers with those of a control group of workers who are not displaced from their jobs over the same period, and estimate equations of the form

$$
\mathrm{LnW}_{\mathrm{it}}=\mathrm{X}_{\mathrm{it}} \beta+\mathrm{Z}_{\mathrm{it}} \gamma+\Sigma_{-1} \mathrm{D}_{\mathrm{it}}^{\mathrm{k}} \delta_{\mathrm{k}}+\mathrm{a}_{\mathrm{i}}+\mathrm{u}_{\mathrm{it}}
$$

Where $X_{i t}$ is a set of fixed and time varying individual controls, $Z_{i t}$ is a set of job characteristics that may influence both wage levels and displacement probabilities. The model also contains a set of year-specific dummy variables to capture aggregate movements in real wage levels.

Given the relatively short span of our data, the set of $\mathrm{D}_{\text {it }}$ dummy variables indicate job displacement in the preceding two, current or next two years. The $\delta_{k}$ coefficients on the dummies are the estimated differences in wages between displaced workers and those who remain measured $\mathrm{k}$ years before or after displacement. If the identification condition for the difference in differences estimate is satisfied, the coefficients should not be significantly different from each other over the various years before displacement because differences would indicate diverging wage growth between displaced workers and those who remain. The dummy variable of the period in which displacement occurs picks out the immediate effect of displacement on the return-to work wage relative to job stayers. The (two) dummy variables for the years after displacement will pick up any persistence in displacement effects. To control for any unobserved individual-specific heterogeneity on wage levels we employ standard fixed and random effects estimation strategies.

\footnotetext{
${ }^{16}$ Real wages are falling over the sample period, hence the significant negative term on the second period time dummy.
} 
The top panel of Table 7 indicates that there are no wage costs of displacement for this sub-sample of displaced workers. The mean wage change for this sample of displaced workers (panel A), when benchmarked against stayers is nearly always positive and between 2 and $4 \log$ points, whether or not unobserved heterogeneity is allowed for, but none of the point estimates are statistically different from zero. Using before and after displacement dummy variables, (panel B), there is some suggestion that wages may begin to fall in the year prior to displacement and that this loss is not recovered in the first year after the return to work in a new job, though the after displacement effects are often only significant at the $10 \%$ level.

\section{Conclusion}

Using Ukrainian household survey data we establish for the first time the extent and the cost of job loss in a labor market of a CIS economy. We estimate that displacement rates over the last decade were between 2.7 and 4.9 percent, indicating that Ukrainian firms have been laying off workers permanently at rates comparable to those in mature market economies. These estimates contradict the frequently held notion that involuntary separations are unimportant in CIS labor markets because of low labor costs.

Multinomial regressions show that displacement is not entirely random. Female workers have a higher probability of being displaced than men. Job losers are typically older workers compared with job quitters, although their educational backgrounds are similar. Educational attainment does not seem to affect displacement throughout the entire period, though. Displacement was particularly high for medium term tenure over the whole sample period. Demographic and job characteristics in previous employment are, however, not the main factors that drive displacement. Instead industry affiliation, ownership type and region matter more. Workers in industry, construction and wholesale and retail trade and hotel services were particularly hard hit by displacement throughout the years 1992 to 2002. In addition, persons residing in Kyiv city are disproportionately affected by permanent layoffs. Once industry, size and regional controls are included a causal effect of ownership type on displacement can only be established for privatized firms, where workers have a slightly lower displacement incidence.

By the standards of industrialized economies, Ukrainian displaced workers have extremely low return rates. While a minority of workers finds reemployment after a very brief spell of non-employment, the majority of workers linger on in non-employment for a very long time. Consequently, the Ukrainian unemployment pool cannot be characterized as 
dynamic as mooted by some. While the individual costs in terms of non-employment spells are large in Ukraine, wage losses due to displacement are rather limited. For those who return to work, there is evidence of a small fall in wages one year prior to displacement, and that this loss is not recovered in the first year after the return to work in a new job. Our analysis makes it clear that the main cost for displaced workers in Ukraine consists in the extremely long nonemployment spell that the average worker experiences after layoff. It is this group of workers lingering on in long-term unemployment that Ukrainian policy makers should focus their attention on. 


\section{References}

Boeri, Tito, Terrell, Katherine, 2002. "Institutional determinants of labor reallocation in transition”, Journal of Economic Perspectives 16, 51-76.

Brown, David and Earle, John, (2002). "Job reallocation and productivity growth under alternative economic systems and policies: Evidence from the Soviet transition", IZA Discussion Paper No. 644, Bonn, Germany.

Djankov, Simeon, Murrell, Peter, 2002. "Enterprise restructuring in transition: a quantitative survey”, Journal of Economic Literature, 60, pp.739-792.

Earle, John and Sabirianova, Klara, (2002). "How late to pay? Understanding wage arrears in Russia”, Journal of Labor Economics, 20(3), pp. 661-707.

Earle, John and Sabirianova-Peter, Klara, (2004), "Contract violations, neighborhood effects, and wage arrears in Russia”, Upjohn Institute staff working paper 04-101, July.

Jacobson, Louis, LaLonde, Robert, Sullivan, Daniel, (1993). The Costs of Worker

Dislocation. W.E. Upjohn Institute, Kalamazoo, MI.

Jenkins, Stephen, 2003. Survival analysis. Available at:

http://www.iser.essex.ac.uk/teaching/stephenj/ec968/pdfs/ec9681notesv6.pdf.

Kletzer, Lori, 1998. “Job displacement. Journal of Economic Perspectives 12, 115-136.

Kuhn, Peter (Ed.), 2002. Losing Work, Moving On: Worker Displacement, an International Perspective. W. E. Upjohn Institute for Employment Research.

Konings, Jozef, Olga Kupets and Lehmann, Hartmut, (2003) "Gross Job Flows in Ukraine: Size, Ownership and Trade Effects”, Economics of Transition, 11(2), p 321-356.

Konings, Jozef and Lehmann, Hartmut, (2002). "Marshall and labor demand in Russia: Going back to basics', Journal of Comparative Economics, 30, pp. 134-59.

Lehmann, Hartmut and John P. Haisken-DeNew (2005) "An Overview of the Ukrainian Longitudinal Monitoring Survey (ULMS)”, Bonn and Essen, mimeo.

Lehmann, Hartmut, Wadsworth, Jonathan, 2000. "Tenures that shook the world. Job tenure and worker turnover in Russia and Poland" Journal of Comparative Economics 28, 639-664.

Lehmann, Hartmut, Wadsworth, Jonathan, Acquisti, Alessandro (1999), "Grime and Punishment: Job Insecurity and Wage Arrears in the Russian Federation.”, Journal of Comparative Economics, 27, pp. 595-617.

Lehmann, Hartmut, Philips, Kaja, Wadsworth, Jonathan, (2005), "The Incidence and Cost of Job Loss in a Transition Economy: Displaced Workers in Estonia", 1989-1999. Journal of Comparative Economics, 33, pp. 59-87 
Lehmann, Hartmut, Kupets, Olga, and Pignatti, Norberto (2005), "Labor Market Adjustment in Ukraine: An Overview", Background Paper prepared for the World Bank Study on the Ukrainian Labor Market, Bologna and Kiev, mimeo.

Orazem, Peter, Vodopivec, Milan, Wu, Ruth, 2004. "Worker displacement during the transition: experience from Slovenia”, Department of Economics Working Papers Series No. 04018. Iowa University. Available at http://www.econ.iastate.edu/research/webpapers/paper_12032 04018.pdf.

Pfann, Gerard, 2001. “Downsizing”, IZA Discussion Paper No. 307. IZA, Bonn.

Podgursky, Michael, Swaim, Paul, 1987. "Job displacement and earnings loss", Industrial and Labor Relations Review 41, 17-29.

Smith, Peter, 2002. Analysis of Failure and Survival Data. Chapman Hall, London.

Standing, Guy, Zsoldos, László, 2001, "Worker Insecurities in Ukrainian Industry: The 2000 ULFS.” ILO, Geneva, April. 
Figure 1. Ukrainian Worker Separation Rates by Year

Separations (sample: working age 15-59 years)

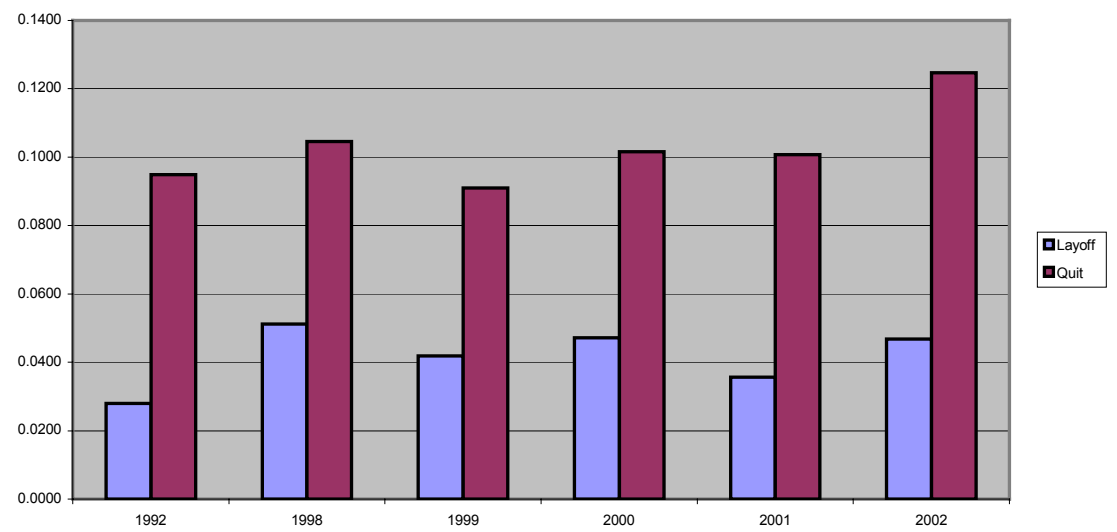

Layoffs (sample: working age 15-59 years)

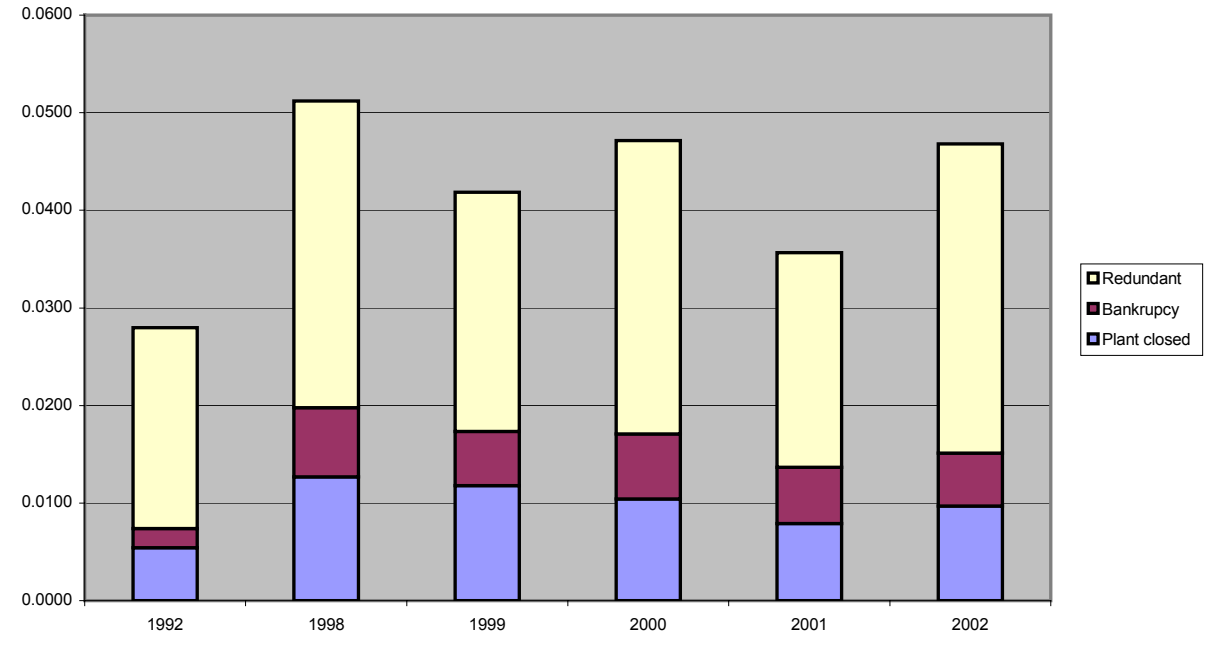

Quits (sample: working age 15-59 years)

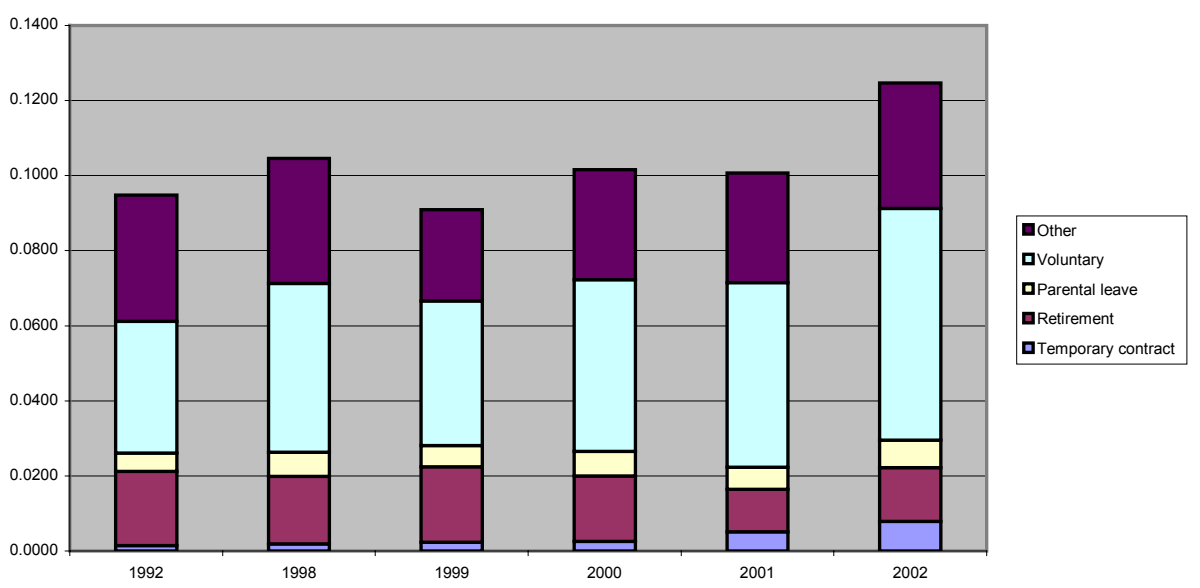


Figure 2. Hazard Rates for Displaced Workers and Job Quits n the Ukraine: 1997-2002
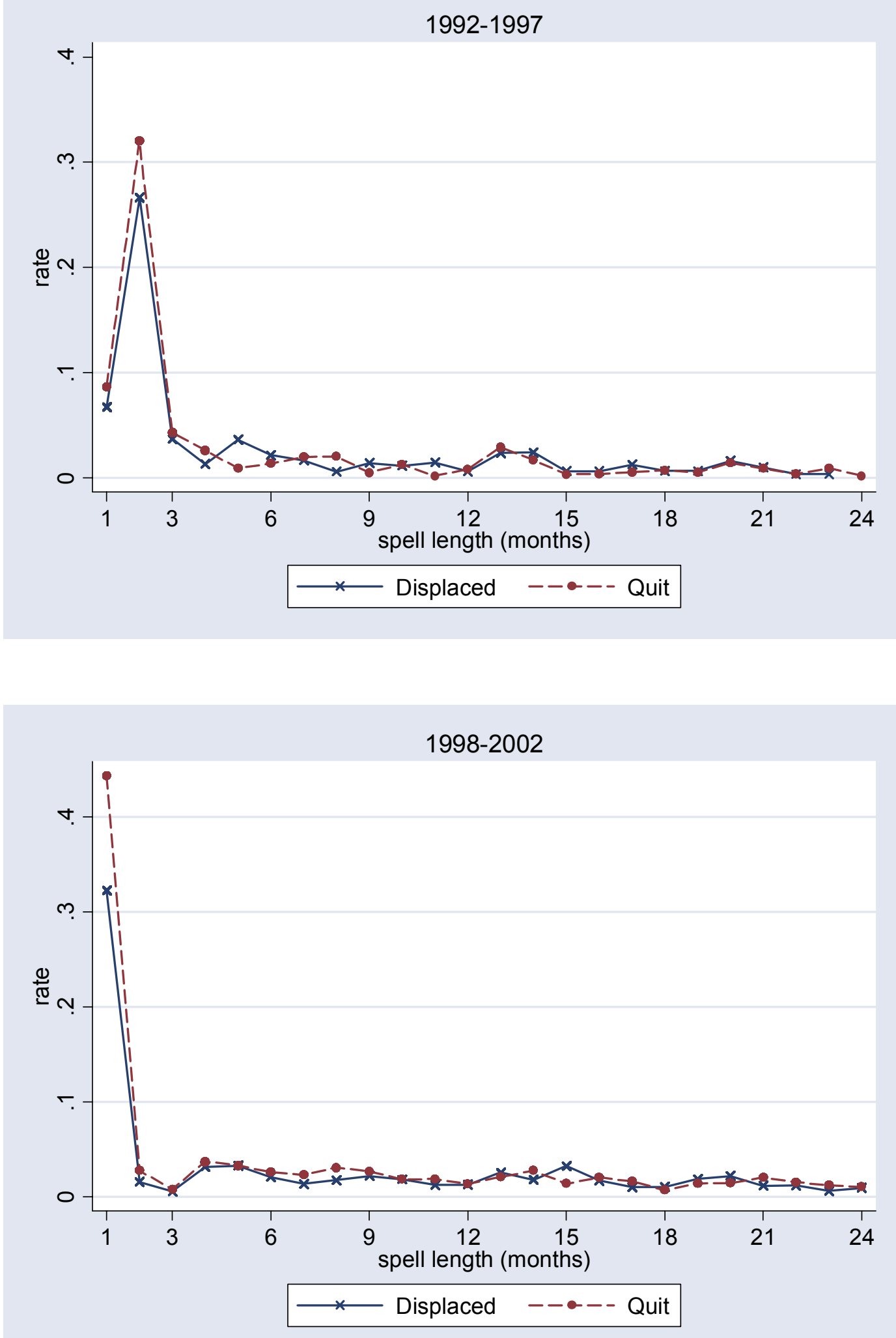


\begin{tabular}{|c|c|c|c|c|c|c|}
\hline & 1992 & 1998 & 1999 & 2000 & 2001 & 2002 \\
\hline Males & 3.3 & 4.5 & 3.8 & 4.5 & 3.6 & 5.5 \\
\hline Females & 2.2 & 5.2 & 4.3 & 4.6 & 3.4 & 3.6 \\
\hline Ukrainian & 2.6 & 4.9 & 3.8 & 4.3 & 3.4 & 4.4 \\
\hline Russian & 2.8 & 4.3 & 5.4 & 5.1 & 4.0 & 4.9 \\
\hline Other & 3.3 & 8.6 & 3.4 & 7.7 & 1.5 & 5.6 \\
\hline \multicolumn{7}{|l|}{ Age } \\
\hline $15-24$ & 4.4 & 5.3 & 5.3 & 4.6 & 3.1 & 5.3 \\
\hline $25-39$ & 3.1 & 5.5 & 4.0 & 4.1 & 3.6 & 3.6 \\
\hline $40-54$ & 1.9 & 4.7 & 4.0 & 5.2 & 3.5 & 4.9 \\
\hline $55+$ & 1.9 & 3.0 & 3.6 & 2.7 & 2.9 & 5.7 \\
\hline \multicolumn{7}{|l|}{ Education } \\
\hline Grades 1-11 & 2.4 & 5.2 & 4.7 & 7.6 & 2.8 & 3.7 \\
\hline General secondary & 3.5 & 5.5 & 4.7 & 5.5 & 4.3 & 6.0 \\
\hline Vocational elementary & 2.7 & 4.6 & 3.5 & 4.0 & 4.9 & 5.8 \\
\hline Vocational secondary & 3.0 & 4.3 & 5.2 & 3.2 & 2.9 & 5.5 \\
\hline Professional secondary/Incomplete higher & 2.3 & 4.8 & 4.3 & 4.5 & 3.8 & 3.4 \\
\hline University & 2.5 & 4.3 & 1.6 & 3.2 & 2.3 & 3.5 \\
\hline \multicolumn{7}{|l|}{ Job tenure } \\
\hline$<1$ Year & 2.8 & - & 4.3 & 3.5 & 3.4 & 5.7 \\
\hline 1Year & 3.6 & 5.4 & 5.3 & 4.9 & 4.2 & 4.7 \\
\hline 2-5Years & 3.7 & 7.1 & 3.9 & 4.7 & 2.3 & 3.8 \\
\hline 6-10 Years & 2.5 & 6.6 & 4.4 & 4.6 & 5.3 & 3.4 \\
\hline 11 Years + & 2.0 & 3.3 & 3.8 & 4.7 & 3.2 & 5.1 \\
\hline \multicolumn{7}{|l|}{ Occupation } \\
\hline Legislators, Senior Managers, Officials & 1.4 & 3.2 & 3.6 & 2.1 & 5.2 & 2.1 \\
\hline Professionals & 1.9 & 2.9 & 2.4 & 3.0 & 1.4 & 2.5 \\
\hline Technicians and Associate Professionals & 1.9 & 5.9 & 2.2 & 3.4 & 2.6 & 2.7 \\
\hline Clerks & 2.2 & 7.7 & 5.8 & 3.5 & 4.4 & 6.4 \\
\hline Service Workers and Market Workers & 3.7 & 5.9 & 6.7 & 5.4 & 1.4 & 4.9 \\
\hline Skilled Agricultural and Fishery Workers & - & 6.6 & 5.0 & 11.5 & 1.5 & 8.2 \\
\hline Craft and Related Trades & 4.5 & 5.4 & 5.2 & 5.1 & 4.0 & 5.9 \\
\hline Plant and Machine Operators & 1.5 & 4.0 & 2.8 & 4.4 & 5.1 & 7.1 \\
\hline Elementary (Unskilled) Occupations & 2.4 & 5.2 & 2.6 & 5.7 & 3.7 & 5.5 \\
\hline \multicolumn{7}{|l|}{ Industry } \\
\hline Agriculture, hunting and forestry & 1.2 & 3.2 & 0.2 & 8.3 & 4.1 & 4.5 \\
\hline Manufacturing and mining & 3.4 & 5.1 & 4.6 & 5.6 & 4.7 & 6.7 \\
\hline Electricity, gas and water supply & 3.2 & 2.6 & - & - & 1.7 & 4.4 \\
\hline Construction & 3.6 & 11.0 & 6.9 & 6.2 & 3.2 & 6.2 \\
\hline Wholesale and retail trade, hotels & 5.2 & 10.1 & 7.8 & 6.4 & 4.4 & 5.8 \\
\hline Transport, storage and communication & 0.7 & 5.4 & 3.6 & 2.0 & 2.4 & 5.3 \\
\hline Financial intermediation, real estate & 5.1 & 9.2 & 4.2 & 1.4 & 6.9 & 6.2 \\
\hline Public Administration and defense & 3.2 & 2.5 & 2.1 & 4.6 & 4.6 & 2.4 \\
\hline Education, health and social work & 1.3 & 1.3 & 1.8 & 1.1 & 1.3 & 1.0 \\
\hline Social and personal service activities & 4.3 & 5.5 & 6.7 & 1.6 & 4.6 & 2.7 \\
\hline Other activities & - & 6.5 & 3.5 & 3.5 & - & 3.6 \\
\hline \multicolumn{7}{|l|}{ Type of enterprise/organization } \\
\hline State & 2.6 & 4.4 & 3.8 & 4.7 & 3.7 & 4.9 \\
\hline Cooperative & 7.3 & 14.0 & 7.1 & 2.0 & 2.1 & - \\
\hline Newly established enterprise & - & 8.7 & 5.9 & 6.9 & 4.0 & 5.3 \\
\hline Privatized enterprise & 4.9 & 5.4 & 4.4 & 3.4 & 3.3 & 4.4 \\
\hline
\end{tabular}




\begin{tabular}{lllllll}
\hline Region & & & & & & \\
West & 1.1 & 2.7 & 1.4 & 2.5 & 1.7 & 1.5 \\
Kyiv City & 2.6 & 5.5 & 3.6 & 2.8 & 5.9 & 3.7 \\
Center \& North & 0.8 & 3.9 & 2.2 & 2.9 & 2.5 & 4.3 \\
East & 1.4 & 3.2 & 2.8 & 3.2 & 2.5 & 3.6 \\
South & 1.7 & 3.7 & 5.2 & 4.0 & 2.5 & 3.8 \\
Total & & & & & & \\
\hline
\end{tabular}




\begin{tabular}{|c|c|c|c|c|}
\hline & \multicolumn{2}{|c|}{ 1992-1997 } & \multicolumn{2}{|c|}{ 1998-2002 } \\
\hline & Displaced & Quit & Displaced & Quit \\
\hline Female & $\begin{array}{c}0.023 \\
(0.010)^{*}\end{array}$ & $\begin{array}{c}0.041 \\
(0.015)^{*}\end{array}$ & $\begin{array}{c}0.005 \\
(0.003)^{*}\end{array}$ & $\begin{array}{c}-0.004 \\
(0.004)\end{array}$ \\
\hline Age 16-24 & $\begin{array}{c}-0.044 \\
(0.018)^{*}\end{array}$ & $\begin{array}{c}-0.151 \\
(0.025)^{*}\end{array}$ & $\begin{array}{c}0.004 \\
(0.005)\end{array}$ & $\begin{array}{c}0.061 \\
(0.011)^{*}\end{array}$ \\
\hline Age $25-34$ & $\begin{array}{c}-0.010 \\
(0.013)\end{array}$ & $\begin{array}{c}-0.192 \\
(0.017)^{*}\end{array}$ & $\begin{array}{l}-0.003 \\
(0.003)\end{array}$ & $\begin{array}{l}-0.003 \\
(0.006)\end{array}$ \\
\hline Age $35-44$ & $\begin{array}{c}0.024 \\
(0.013)\end{array}$ & $\begin{array}{c}-0.233 \\
(0.015)^{*}\end{array}$ & $\begin{array}{c}0.002 \\
(0.003)\end{array}$ & $\begin{array}{c}-0.023 \\
(0.005)^{*}\end{array}$ \\
\hline \multicolumn{5}{|l|}{ Ethnicity } \\
\hline Ukrainian & $\begin{array}{c}0.005 \\
(0.024)\end{array}$ & $\begin{array}{c}-0.099 \\
(0.037)^{*}\end{array}$ & $\begin{array}{c}-0.006 \\
(0.006)\end{array}$ & $\begin{array}{r}-0.0005 \\
(0.011)\end{array}$ \\
\hline Russian & $\begin{array}{c}0.026 \\
(0.029)\end{array}$ & $\begin{array}{c}-0.073 \\
(0.035)^{*}\end{array}$ & $\begin{array}{c}-0.004 \\
(0.006)\end{array}$ & $\begin{array}{c}0.012 \\
(0.013)\end{array}$ \\
\hline \multicolumn{5}{|l|}{ Education } \\
\hline General Secondary & $\begin{array}{c}0.031 \\
(0.016)\end{array}$ & $\begin{array}{c}-0.068 \\
(0.020)^{*}\end{array}$ & $\begin{array}{c}0.002 \\
(0.004)\end{array}$ & $\begin{array}{l}-0.011 \\
(0.006)\end{array}$ \\
\hline $\begin{array}{l}\text { Vocational } \\
\text { Elementary }\end{array}$ & $\begin{array}{c}0.011 \\
(0.023)\end{array}$ & $\begin{array}{l}-0.056 \\
(0.030)\end{array}$ & $\begin{array}{l}-0.001 \\
(0.005)\end{array}$ & $\begin{array}{l}-0.011 \\
(0.007)\end{array}$ \\
\hline $\begin{array}{l}\text { Vocational } \\
\text { Secondary }\end{array}$ & $\begin{array}{c}0.029 \\
(0.019)\end{array}$ & $\begin{array}{l}-0.046 \\
(0.024)\end{array}$ & $\begin{array}{l}-0.002 \\
(0.004)\end{array}$ & $\begin{array}{l}-0.007 \\
(0.006)\end{array}$ \\
\hline $\begin{array}{l}\text { Professional } \\
\text { /Incomplete Higher }\end{array}$ & $\begin{array}{c}0.007 \\
(0.015)\end{array}$ & $\begin{array}{c}-0.075 \\
(0.020)^{*}\end{array}$ & $\begin{array}{l}0.0002 \\
(0.004)\end{array}$ & $\begin{array}{l}-0.007 \\
(0.006)\end{array}$ \\
\hline University & $\begin{array}{c}0.010 \\
(0.018)\end{array}$ & $\begin{array}{c}-0.115 \\
(0.022)^{*}\end{array}$ & $\begin{array}{l}-0.008 \\
(0.004)\end{array}$ & $\begin{array}{l}-0.008 \\
(0.006)\end{array}$ \\
\hline \multicolumn{5}{|l|}{ Tenure } \\
\hline$<1$ year & $\begin{array}{c}-0.016 \\
(0.021)\end{array}$ & $\begin{array}{c}0.242 \\
(0.035)^{*}\end{array}$ & $\begin{array}{c}-0.002 \\
(0.004)\end{array}$ & $\begin{array}{c}0.035 \\
(0.010)^{*}\end{array}$ \\
\hline 1 year & $\begin{array}{c}0.059 \\
(0.024)^{*}\end{array}$ & $\begin{array}{c}0.097 \\
(0.032)^{*}\end{array}$ & $\begin{array}{c}0.008 \\
(0.005)\end{array}$ & $\begin{array}{c}0.058 \\
(0.011)^{*}\end{array}$ \\
\hline 2 to 5 years & $\begin{array}{c}0.038 \\
(0.015)^{*}\end{array}$ & $\begin{array}{c}0.097 \\
(0.021)^{*}\end{array}$ & $\begin{array}{c}0.006 \\
(0.004)\end{array}$ & $\begin{array}{c}0.031 \\
(0.007)^{*}\end{array}$ \\
\hline 6 to 10 years & $\begin{array}{c}0.027 \\
(0.015)\end{array}$ & $\begin{array}{l}-0.006 \\
(0.022)\end{array}$ & $\begin{array}{c}0.016 \\
(0.005)^{*}\end{array}$ & $\begin{array}{c}0.024 \\
(0.007)^{*}\end{array}$ \\
\hline \multicolumn{5}{|l|}{ Ownership } \\
\hline New enterprise & $\begin{array}{l}-0.034 \\
(0.032)\end{array}$ & $\begin{array}{c}-0.118 \\
(0.051)^{*}\end{array}$ & $\begin{array}{l}-0.002 \\
(0.004)\end{array}$ & $\begin{array}{c}0.007 \\
(0.007)\end{array}$ \\
\hline Cooperative & $\begin{array}{c}0.122 \\
(0.048)^{*}\end{array}$ & $\begin{array}{c}0.057 \\
(0.059)\end{array}$ & $\begin{array}{c}0.001 \\
(0.010)\end{array}$ & $\begin{array}{c}0.004 \\
(0.019)\end{array}$ \\
\hline Privatized enterprise & $\begin{array}{c}-0.046 \\
(0.014)^{*}\end{array}$ & $\begin{array}{c}-0.206 \\
(0.022)^{*}\end{array}$ & $\begin{array}{c}-0.007 \\
(0.003)^{*}\end{array}$ & $\begin{array}{c}-0.018 \\
(0.005)^{*}\end{array}$ \\
\hline Industry & & & & \\
\hline
\end{tabular}




\begin{tabular}{|c|c|c|c|c|}
\hline Agriculture & $\begin{array}{c}-0.077 \\
(0.012)^{*}\end{array}$ & $\begin{array}{c}0.019 \\
(0.025)\end{array}$ & $\begin{array}{l}-0.001 \\
(0.004)\end{array}$ & $\begin{array}{c}0.008 \\
(0.007)\end{array}$ \\
\hline Energy & $\begin{array}{c}-0.078 \\
(0.021)^{*}\end{array}$ & $\begin{array}{l}-0.016 \\
(0.054)\end{array}$ & $\begin{array}{c}-0.021 \\
(0.004) *\end{array}$ & $\begin{array}{c}-0.029 \\
(0.010)^{*}\end{array}$ \\
\hline Construction & $\begin{array}{l}-0.015 \\
(0.019)\end{array}$ & $\begin{array}{c}0.121 \\
(0.037)^{*}\end{array}$ & $\begin{array}{c}0.009 \\
(0.006)\end{array}$ & $\begin{array}{c}0.004 \\
(0.010)\end{array}$ \\
\hline Retail & $\begin{array}{c}0.030 \\
(0.021)\end{array}$ & $\begin{array}{c}0.096 \\
(0.034) *\end{array}$ & $\begin{array}{c}0.006 \\
(0.005)\end{array}$ & $\begin{array}{c}0.002 \\
(0.008)\end{array}$ \\
\hline Transport & $\begin{array}{c}-0.077 \\
(0.013)^{*}\end{array}$ & $\begin{array}{c}0.017 \\
(0.030)\end{array}$ & $\begin{array}{c}-0.011 \\
(0.004)^{*}\end{array}$ & $\begin{array}{c}-0.015 \\
(0.007)^{*}\end{array}$ \\
\hline Financial & $\begin{array}{l}-0.038 \\
(0.030)\end{array}$ & $\begin{array}{l}-0.068 \\
(0.058)\end{array}$ & $\begin{array}{c}-0.004 \\
(0.007)\end{array}$ & $\begin{array}{c}-0.010 \\
(0.014)\end{array}$ \\
\hline $\begin{array}{l}\text { Public } \\
\text { Administration }\end{array}$ & $\begin{array}{l}-0.017 \\
(0.020)\end{array}$ & $\begin{array}{c}0.053 \\
(0.038)\end{array}$ & $\begin{array}{c}-0.014 \\
(0.004)^{*}\end{array}$ & $\begin{array}{c}-0.024 \\
(0.008)^{*}\end{array}$ \\
\hline Education, health & $\begin{array}{c}-0.099 \\
(0.011)^{*}\end{array}$ & $\begin{array}{l}-0.017 \\
(0.026)\end{array}$ & $\begin{array}{c}-0.031 \\
(0.003)^{*}\end{array}$ & $\begin{array}{c}-0.040 \\
(0.006)^{*}\end{array}$ \\
\hline Other service & $\begin{array}{l}-0.001 \\
(0.021)\end{array}$ & $\begin{array}{l}-0.001 \\
(0.036)\end{array}$ & $\begin{array}{c}-0.009 \\
(0.004)^{*}\end{array}$ & $\begin{array}{c}0.001 \\
(0.009)\end{array}$ \\
\hline Other activities & $\begin{array}{l}-0.002 \\
(0.064)\end{array}$ & $\begin{array}{l}-0.025 \\
(0.114)\end{array}$ & $\begin{array}{l}-0.006 \\
(0.011)\end{array}$ & $\begin{array}{l}-0.006 \\
(0.019)\end{array}$ \\
\hline \multicolumn{5}{|l|}{ Firm size } \\
\hline $100-249$ & $\begin{array}{c}0.026 \\
(0.017)\end{array}$ & $\begin{array}{l}-0.028 \\
(0.023)\end{array}$ & $\begin{array}{l}-0.001 \\
(0.004)\end{array}$ & $\begin{array}{c}0.003 \\
(0.006)\end{array}$ \\
\hline $250-499$ & $\begin{array}{l}-0.010 \\
(0.017)\end{array}$ & $\begin{array}{c}0.034 \\
(0.026)\end{array}$ & $\begin{array}{c}0.002 \\
(0.004)\end{array}$ & $\begin{array}{l}-0.013 \\
(0.007)\end{array}$ \\
\hline $500-999$ & $\begin{array}{c}0.013 \\
(0.019)\end{array}$ & $\begin{array}{c}0.049 \\
(0.028)\end{array}$ & $\begin{array}{c}0.001 \\
(0.005)\end{array}$ & $\begin{array}{c}-0.021 \\
(0.007)^{*}\end{array}$ \\
\hline $1000+$ & $\begin{array}{l}-0.005 \\
(0.014)\end{array}$ & $\begin{array}{c}0.026 \\
(0.023)\end{array}$ & $\begin{array}{l}-0.006 \\
(0.003)\end{array}$ & $\begin{array}{l}-0.008 \\
(0.006)\end{array}$ \\
\hline \multicolumn{5}{|l|}{ Region } \\
\hline West & $\begin{array}{c}-0.046 \\
(0.013)^{*}\end{array}$ & $\begin{array}{c}-0.225 \\
(0.018)^{*}\end{array}$ & $\begin{array}{c}-0.038 \\
(0.002)^{*}\end{array}$ & $\begin{array}{c}-0.086 \\
(0.003)^{*}\end{array}$ \\
\hline East & $\begin{array}{c}-0.049 \\
(0.012)^{*}\end{array}$ & $\begin{array}{c}-0.215 \\
(0.018)^{*}\end{array}$ & $\begin{array}{c}-0.039 \\
(0.003)^{*}\end{array}$ & $\begin{array}{c}-0.096 \\
(0.004)^{*}\end{array}$ \\
\hline Center and North & $\begin{array}{c}-0.057 \\
(0.012)^{*}\end{array}$ & $\begin{array}{c}-0.225 \\
(0.018)^{*}\end{array}$ & $\begin{array}{c}-0.034 \\
(0.002)^{*}\end{array}$ & $\begin{array}{c}-0.088 \\
(0.004)^{*}\end{array}$ \\
\hline South & $\begin{array}{c}-0.048 \\
(0.013)^{*}\end{array}$ & $\begin{array}{c}-0.218 \\
(0.018)^{*}\end{array}$ & $\begin{array}{c}-0.028 \\
(0.002)^{*}\end{array}$ & $\begin{array}{c}-0.085 \\
(0.003)^{*}\end{array}$ \\
\hline $\mathrm{N}$ & 4977 & & 19224 & \\
\hline Pseudo $\mathrm{R}^{2}$ & 0.0990 & & 0.1013 & \\
\hline
\end{tabular}

Source: ULMS Notes: coefficients are marginal effects. Clustered standard errors in brackets. ${ }^{*}$ statistically significant at the $5 \%$ level; Default categories are male, age 45-60, other nationality, grade 1 to 11 , tenure $>10$ years, previously working in state owned firm, production sector, firm $>1000$ employees, Kyiv city. Full-time jobs only. 
Table 3. Cumulative Return Rates for Job Movers: 1992 to 2002

\begin{tabular}{lcccc}
\hline & \multicolumn{2}{c}{$1992-1997$} & \multicolumn{2}{c}{$1998-2002$} \\
\hline \% returning & Displaced & Quit & Displaced & Quit \\
\hline$<1$ month (job to job) & 6.7 & 8.6 & 32.2 & 44.3 \\
$<3$ months & 31.5 & 40.6 & 33.6 & 46.3 \\
$<6$ months & 38.6 & 43.4 & 39.1 & 51.2 \\
$<=12$ months & 42.6 & 47.1 & 44.7 & 57.2 \\
Median completed & 5 & 3 & & 1 \\
duration (months) & 1 & 1 & & 1 \\
Median number of spells & & & & 1 \\
$\mathrm{~N}$ & 434 & 1169 & 862 & 1714 \\
\hline
\end{tabular}

Source: ULMS. Notes ( i) The fractions are based on one minus the Kaplan-Meier survivor function. (ii) Retirements are excluded from quits. 
Table 4. Discrete Piecewise Proportional Hazard Estimates of Jobless Spell Excluding Movements into Retirement (Gamma Unobserved Heterogeneity)

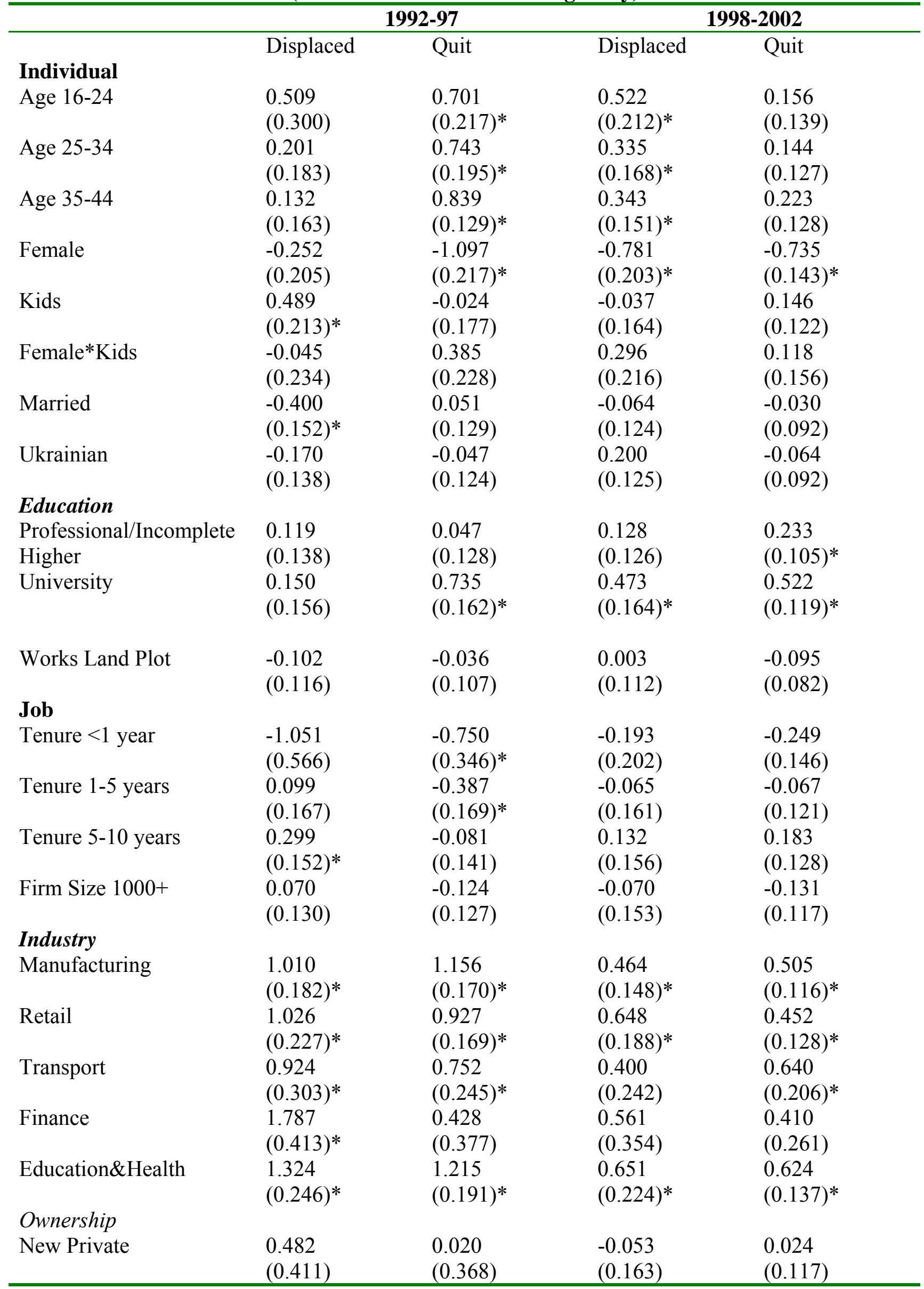




\begin{tabular}{lllll}
\hline Privatised/Foreign & -0.720 & -0.507 & 0.106 & -0.015 \\
Region & $(0.497)$ & $(0.337)$ & $(0.204)$ & $(0.133)$ \\
Central/North & & & & \\
& 0.001 & -0.007 & -0.389 & 0.003 \\
Kyiv & $(0.156)$ & $(0.169)$ & $(0.151)^{*}$ & $(0.111)$ \\
& -0.334 & 0.052 & 0.201 & 0.291 \\
South & $(0.239)$ & $(0.204)$ & $(0.214)$ & $(0.151)$ \\
& -0.062 & 0.162 & 0.086 & -0.019 \\
West & $(0.198)$ & $(0.171)$ & $(0.164)$ & $(0.128)$ \\
Duration & -0.210 & -0.094 & -0.217 & -0.205 \\
$<1$ month & $(0.162)$ & $(0.168)$ & $(0.162)$ & $(0.122)$ \\
& 1.569 & 0.957 & 2.830 & 3.040 \\
$1-3$ months & $(0.364)^{*}$ & $(0.294)^{*}$ & $(0.199)^{*}$ & $(0.165)^{*}$ \\
& 2.326 & 2.178 & -0.192 & 0.050 \\
$3-6$ months & $(0.198)^{*}$ & $(0.149)^{*}$ & $(0.251)$ & $(0.183)$ \\
& 0.771 & -0.169 & 0.194 & 0.304 \\
Constant & $(0.234)^{*}$ & $(0.230)$ & $(0.220)$ & $(0.169)$ \\
& -4.797 & -3.942 & -4.235 & -4.020 \\
Ln $\left(\sigma_{\text {gamma }}^{2}\right)$ & $(0.332)^{*}$ & $(0.357)^{*}$ & $(0.291)^{*}$ & $(0.245)^{*}$ \\
& & & & \\
Log L & -2.934 & -0.374 & -2.668 & -1.878 \\
\hline So & $(5.208)$ & $(0.348)$ & $(3.886)$ & $(1.247)$ \\
\hline
\end{tabular}

Source: ULMS Note: Standard errors in brackets. * significant at 5\% level. Default categories are male aged 45-60, single, no children, previously working in state owned firm, living in eastern Ukraine, production sector, firm $<100$ employees, previous job tenure 10 years + , out of work 6months + . Full-time jobs only. Dummy variable for missing values on firm size included. 
Table 5. After-Displacement Wage Determinants: 1998-2002

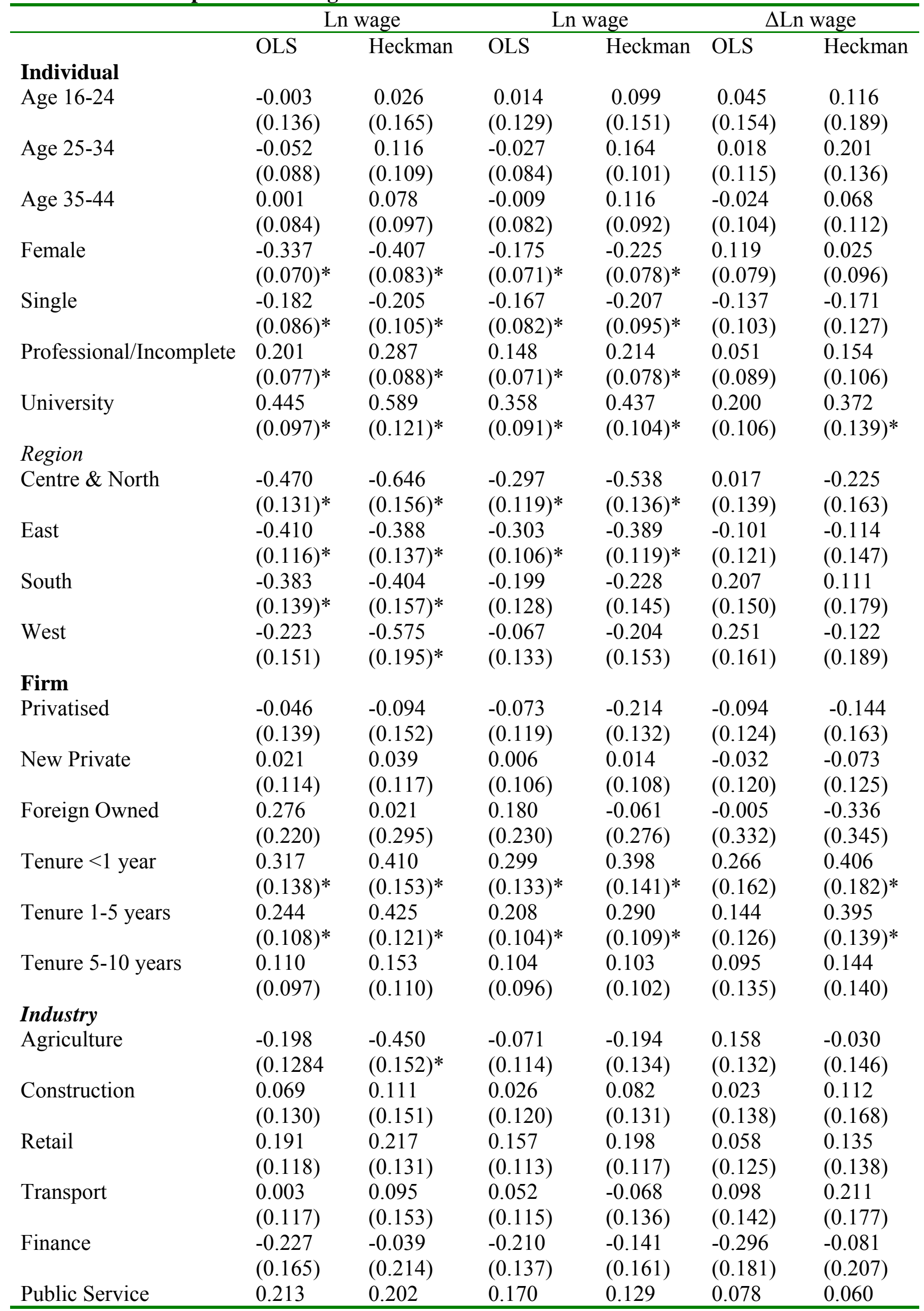




\begin{tabular}{|c|c|c|c|c|c|c|}
\hline & $(0.143)$ & $(0.204)$ & $(0.132)$ & $(0.160)$ & $(0.166)$ & $(0.221)$ \\
\hline \multirow[t]{2}{*}{ Education/Health } & -0.154 & -0.158 & -0.040 & -0.018 & 0.149 & 0.100 \\
\hline & $(0.149)$ & $(0.173)$ & $(0.150)$ & $(0.164)$ & $(0.200)$ & $(0.210)$ \\
\hline \multirow[t]{2}{*}{ Other Services } & 0.039 & 0.135 & 0.087 & 0.068 & 0.072 & 0.209 \\
\hline & $(0.152)$ & $(0.171)$ & $(0.153)$ & $(0.164)$ & $(0.192)$ & $(0.211)$ \\
\hline \multirow{2}{*}{ Firm_size 100-999 } & 0.172 & 0.323 & 0.161 & 0.293 & 0.140 & 0.312 \\
\hline & $(0.093)$ & $(0.111)^{*}$ & $(0.083)$ & $(0.095)^{*}$ & $(0.102)$ & $(0.126)^{*}$ \\
\hline \multirow[t]{2}{*}{ Firm Size 1000+ } & 0.229 & 0.363 & 0.168 & 0.279 & 0.056 & 0.215 \\
\hline & $(0.114)^{*}$ & $(0.138)^{*}$ & $(0.112)$ & $(0.122)^{*}$ & $(0.142)$ & $(0.159)$ \\
\hline \multirow[t]{2}{*}{ Change Industry } & -0.140 & -0.225 & -0.147 & -0.220 & -0.161 & -0.193 \\
\hline & $(0.067)^{*}$ & $(0.073)^{*}$ & $(0.062)^{*}$ & $(0.063)^{*}$ & $(0.072)^{*}$ & $(0.067)^{*}$ \\
\hline \multirow[t]{2}{*}{ Change Occupation } & -0.059 & -0.005 & 0.001 & 0.021 & 0.118 & 0.118 \\
\hline & $(0.067)$ & $(0.060)$ & $(0.066)$ & $(0.056)$ & $(0.080)$ & $(0.070)$ \\
\hline \multirow[t]{2}{*}{ Change Region } & 0.351 & 0.300 & 0.327 & 0.320 & 0.282 & 0.261 \\
\hline & $(0.138)^{*}$ & $(0.128)^{*}$ & $(0.124)^{*}$ & $(0.100)^{*}$ & $(0.152)$ & $(0.100)^{*}$ \\
\hline \multirow[t]{2}{*}{ Move to Privatised } & 0.127 & 0.198 & 0.109 & 0.114 & 0.074 & 0.066 \\
\hline & $(0.188)$ & $(0.183)$ & $(0.191)$ & $(0.204)$ & $(0.240)$ & $(0.221)$ \\
\hline \multirow[t]{2}{*}{ Move to foreign-owned } & -0.001 & 0.081 & 0.034 & 0.128 & 0.096 & 0.259 \\
\hline & $(0.194)$ & $(0.140)$ & $(0.145)$ & $(0.121)$ & $(0.134)$ & $(0.141)$ \\
\hline \multicolumn{7}{|l|}{ Time Out } \\
\hline \multirow[t]{2}{*}{ Job-to-Job } & 0.183 & 0.163 & 0.136 & 0.133 & 0.051 & 0.008 \\
\hline & $(0.073)^{*}$ & $(0.060)^{*}$ & $(0.069)^{*}$ & $(0.058)^{*}$ & $(0.085)$ & $(0.075)$ \\
\hline \multirow[t]{2}{*}{$1-5$ months } & 0.037 & 0.062 & 0.012 & 0.036 & -0.033 & -0.135 \\
\hline & $(0.129)$ & $(0.116)$ & $(0.126)$ & $(0.113)$ & $(0.152)$ & $(0.128)$ \\
\hline \multirow[t]{2}{*}{ Ln(old_wage) } & & & 0.355 & 0.440 & & \\
\hline & & & $(0.058)^{*}$ & $(0.069)^{*}$ & & \\
\hline \multirow[t]{2}{*}{ Lambda } & & 0.698 & & 0.561 & & 0.772 \\
\hline & & $(0.112)^{*}$ & & $(0.069)^{*}$ & & $(0.139)^{*}$ \\
\hline \multirow[t]{2}{*}{ Constant } & 4.839 & 3.731 & 3.023 & 2.141 & -0.268 & -1.459 \\
\hline & $(0.178)^{*}$ & $(0.283)^{*}$ & $(0.354)^{*}$ & $(0.427)^{*}$ & $(0.204)$ & $(0.341)^{*}$ \\
\hline $\mathrm{R}^{2}$ & 0.42 & & 0.48 & & 0.18 & \\
\hline
\end{tabular}

Robust standard errors in brackets * significant at $5 \%$. Default categories are male aged 45-60, single, no children, previously working in state owned firm, living in eastern Ukraine, production sector, firm $<100$ employees, previous job tenure 10 years + , out of work 6months + . Full-time jobs only. Dummy variable for missing values on firm size included. Sample size 263 


\begin{tabular}{|c|c|c|c|}
\hline & (1) & (2) & (3) \\
\hline \multicolumn{4}{|l|}{ Panel A } \\
\hline \multirow[t]{2}{*}{$2^{\text {nd }}$ Period Dummy } & -0.003 & -0.001 & -0.001 \\
\hline & $(0.003)$ & $(0.002)$ & $(0.002)$ \\
\hline \multirow[t]{2}{*}{ Displaced } & -0.059 & -0.102 & -0.089 \\
\hline & $(0.051)$ & $(0.046)^{*}$ & $(0.051)$ \\
\hline \multirow[t]{2}{*}{ Displaced $* 2^{\text {nd }}$ Period } & 0.007 & 0.002 & 0.049 \\
\hline & $(0.060)$ & $(0.059)$ & $(0.061)$ \\
\hline Individual controls & No & Yes & Yes \\
\hline Job controls & No & No & Yes \\
\hline R-squared & 0.03 & 0.19 & 0.26 \\
\hline \multicolumn{4}{|l|}{ Panel B } \\
\hline \multirow[t]{2}{*}{$2^{\text {nd }}$ Period Dummy } & -0.098 & 0.002 & 0.002 \\
\hline & $(0.007)^{*}$ & $(0.003)$ & $(0.003)$ \\
\hline \multirow[t]{2}{*}{ Spell Length } & -0.043 & -0.028 & -0.020 \\
\hline & $(0.040)$ & $(0.033)$ & $(0.031)$ \\
\hline \multirow[t]{2}{*}{ Spell length $* 2^{\text {nd }}$ Period } & -0.107 & -0.068 & 0.024 \\
\hline & $(0.128)$ & $(0.129)$ & $(0.146)$ \\
\hline Individual controls & No & Yes & Yes \\
\hline Job controls & No & No & Yes \\
\hline R-squared & 0.01 & 0.19 & 0.26 \\
\hline Sample size & 9785 & 9785 & 9785 \\
\hline
\end{tabular}

Notes: Robust standard errors in parentheses; ${ }^{*}$ significant at 5\%. Regressions also include year dummies. 
Table 7. Short-Run and Longer-Term Wage Costs of Displacement: 1998 - 2002

\begin{tabular}{|c|c|c|c|c|c|c|c|c|c|}
\hline & OLS & $\begin{array}{c}\text { Fixed } \\
\text { Effects }\end{array}$ & $\begin{array}{c}\text { Random } \\
\text { Effects }\end{array}$ & OLS & $\begin{array}{c}\text { Fixed } \\
\text { Effects }\end{array}$ & $\begin{array}{l}\text { Random } \\
\text { Effects }\end{array}$ & OLS & $\begin{array}{c}\text { Fixed } \\
\text { Effects }\end{array}$ & $\begin{array}{c}\text { Random } \\
\text { Effects }\end{array}$ \\
\hline Panel A & 1 & 2 & 3 & 4 & 5 & 6 & 7 & 8 & 9 \\
\hline Displaced & $\begin{array}{l}0.029 \\
(0.032)\end{array}$ & $\begin{array}{l}0.042 \\
(0.027)\end{array}$ & $\begin{array}{l}0.040 \\
(0.025)\end{array}$ & $\begin{array}{l}-0.026 \\
(0.030)\end{array}$ & $\begin{array}{l}0.030 \\
(0.026)\end{array}$ & $\begin{array}{l}0.022 \\
(0.025)\end{array}$ & $\begin{array}{l}0.029 \\
(0.037)\end{array}$ & $\begin{array}{l}0.030 \\
(0.026)\end{array}$ & $\begin{array}{l}0.037 \\
(0.026)\end{array}$ \\
\hline $\begin{array}{l}\text { Individual controls } \\
\text { Job controls } \\
\text { Panel B } \\
\text { Years Before/After } \\
\text { Displacement }\end{array}$ & $\begin{array}{l}\text { No } \\
\text { No }\end{array}$ & $\begin{array}{l}\text { No } \\
\text { No }\end{array}$ & $\begin{array}{l}\text { No } \\
\text { No }\end{array}$ & $\begin{array}{l}\text { Yes } \\
\text { No }\end{array}$ & $\begin{array}{l}\text { Yes } \\
\text { No }\end{array}$ & $\begin{array}{l}\text { Yes } \\
\text { No }\end{array}$ & $\begin{array}{l}\text { Yes } \\
\text { Yes }\end{array}$ & $\begin{array}{l}\text { Yes } \\
\text { Yes }\end{array}$ & $\begin{array}{l}\text { Yes } \\
\text { Yes }\end{array}$ \\
\hline 2 years before & $\begin{array}{l}0.048 \\
(0.070)\end{array}$ & $\begin{array}{l}-0.077 \\
(0.039)^{*}\end{array}$ & $\begin{array}{l}-0.061 \\
(0.038)\end{array}$ & $\begin{array}{l}-0.003 \\
(0.051)\end{array}$ & $\begin{array}{l}-0.029 \\
(0.034)\end{array}$ & $\begin{array}{l}-0.027 \\
(0.033)\end{array}$ & $\begin{array}{l}-0.026 \\
(0.059)\end{array}$ & $\begin{array}{l}-0.068 \\
(0.039)\end{array}$ & $\begin{array}{l}-0.059 \\
(0.038)\end{array}$ \\
\hline 1 year before & $\begin{array}{l}-0.021 \\
(0.060)\end{array}$ & $\begin{array}{l}-0.130 \\
(0.034)^{*}\end{array}$ & $\begin{array}{l}-0.115 \\
(0.033)^{*}\end{array}$ & $\begin{array}{l}-0.059 \\
(0.047)\end{array}$ & $\begin{array}{l}-0.072 \\
(0.030)^{*}\end{array}$ & $\begin{array}{l}-0.069 \\
(0.029) *\end{array}$ & $\begin{array}{l}-0.091 \\
(0.054)\end{array}$ & $\begin{array}{l}-0.124 \\
(0.034)^{*}\end{array}$ & $\begin{array}{l}-0.117 \\
(0.032) *\end{array}$ \\
\hline Year of Displacement & $\begin{array}{l}0.037 \\
(0.058)\end{array}$ & $\begin{array}{l}-0.063 \\
(0.033)\end{array}$ & $\begin{array}{l}-0.049 \\
(0.032)\end{array}$ & $\begin{array}{l}-0.051 \\
(0.049)\end{array}$ & $\begin{array}{l}-0.065 \\
(0.030)^{*}\end{array}$ & $\begin{array}{l}-0.062 \\
(0.029)^{*}\end{array}$ & $\begin{array}{l}0.060 \\
(0.069)\end{array}$ & $\begin{array}{l}-0.045 \\
(0.036)\end{array}$ & $\begin{array}{l}-0.023 \\
(0.035)\end{array}$ \\
\hline 1 year after & $\begin{array}{l}0.013 \\
(0.065)\end{array}$ & $\begin{array}{l}-0.071 \\
(0.036)^{*}\end{array}$ & $\begin{array}{l}-0.057 \\
(0.035)\end{array}$ & $\begin{array}{l}-0.061 \\
(0.056)\end{array}$ & $\begin{array}{l}-0.062 \\
(0.033)\end{array}$ & $\begin{array}{l}-0.060 \\
(0.032)\end{array}$ & $\begin{array}{l}-0.008 \\
(0.063)\end{array}$ & $\begin{array}{l}-0.075 \\
(0.036) *\end{array}$ & $\begin{array}{l}-0.060 \\
(0.035)\end{array}$ \\
\hline 2 years after & $\begin{array}{l}-0.007 \\
(0.067)\end{array}$ & $\begin{array}{l}-0.045 \\
(0.039)\end{array}$ & $\begin{array}{l}-0.033 \\
(0.038)\end{array}$ & $\begin{array}{l}-0.076 \\
(0.057)\end{array}$ & $\begin{array}{l}-0.047 \\
(0.036)\end{array}$ & $\begin{array}{l}-0.046 \\
(0.035)\end{array}$ & $\begin{array}{l}-0.013 \\
(0.063)\end{array}$ & $\begin{array}{l}-0.056 \\
(0.039)\end{array}$ & $\begin{array}{l}-0.041 \\
(0.038)\end{array}$ \\
\hline
\end{tabular}

Robust standard errors in parentheses. * significant at 5\% level; Sample size 7722. Sample restricted to those with 6 continuous wage observations. 


\section{Appendix}

Table A1. Reasons for leaving job classification ${ }^{17}$

\begin{tabular}{lc}
\hline \multicolumn{1}{c}{ REASON } & CLASSIFICATION \\
\hline 1 Closing down of enterprise/organization & Displacement \\
2 Reorganization of enterprise/organization & Displacement \\
3 Bankruptcy of enterprise/organization & Displacement \\
4 Privatization of enterprise/organization & Displacement \\
5 Dismissal initiated by employer & Displacement \\
6 Personnel reduction & Displacement \\
7 Expiring of employment contract & Quit \\
8 Expiring of probation time & Quit \\
9 Military service & Quit \\
10 Imprisonment & Quit \\
11 Own illness or injury & Quit \\
12 Studies & Quit \\
13 Retirement & Quit \\
14 Early retirement & Quit \\
15 Marriage & Quit \\
16 Parental leave & Quit \\
17 Need to take care of other members of family & Quit \\
18 Change of residence & Quit \\
19 Wanted/was proposed higher salary & Quit \\
20 Wanted/was proposed better working conditions & Quit \\
21 Wanted/was proposed more interesting work & Quit \\
23 Wanted to start own business & Quit \\
24 End of farming/sole proprietorship & Quit \\
\hline
\end{tabular}

${ }^{17}$ The ULMS allows the respondent to give multiple answers as to the reasons for a job separation. In cases where this occurs, we use the following classification criteria:

- We ignore displacements caused by expiration of the employment contract (we focus on displacement of workers with permanent positions);

- If any of the answers is closing down of enterprise/organization, the person is displaced

- If among the answers there is no displacement, priority goes to answers suggesting a voluntary quit (wanted/was proposed higher salary, better working conditions, more interesting work, wanted to start own business, studies, marriage, parental leave, need to take care of family member)

- in all the remaining cases priority goes again to causes of displacement (reorganization, bankruptcy, privatization, personnel reduction);

- when we have dismissal initiated by the employer together with any of the causes classified as quit, we have a quit. 


\begin{tabular}{|c|c|c|c|c|c|c|}
\hline & 1992 & 1998 & 1999 & 2000 & 2001 & 2002 \\
\hline Males & 3.2 & 4.5 & 3.7 & 4.3 & 3.6 & 5.2 \\
\hline Females & 2.2 & 5.2 & 4.3 & 4.7 & 3.3 & 3.5 \\
\hline Ukrainian & 2.6 & 4.8 & 3.7 & 4.2 & 3.5 & 4.2 \\
\hline Russian & 2.8 & 4.3 & 5.5 & 5.2 & 3.7 & 4.7 \\
\hline Other & 3.3 & 8.2 & 3.8 & 7.3 & 1.4 & 5.4 \\
\hline \multicolumn{7}{|l|}{ Age } \\
\hline $15-24$ & 4.4 & 5.3 & 5.3 & 4.6 & 3.1 & 5.3 \\
\hline $25-39$ & 3.1 & 5.5 & 4.0 & 4.1 & 3.6 & 3.6 \\
\hline $40-54$ & 1.9 & 4.7 & 4.0 & 5.2 & 3.5 & 4.9 \\
\hline $55-64$ & 1.7 & 3.1 & 3.3 & 3.6 & 2.6 & 4.4 \\
\hline $65+$ & - & 4.4 & 3.8 & 1.5 & 3.8 & 1.0 \\
\hline \multicolumn{7}{|l|}{ Education } \\
\hline Grades 1-11 & 2.3 & 5.1 & 4.6 & 7.1 & 2.9 & 3.5 \\
\hline General secondary & 3.5 & 5.4 & 4.5 & 5.4 & 4.1 & 5.8 \\
\hline Vocational elementary & 2.7 & 4.4 & 3.3 & 3.8 & 4.7 & 5.5 \\
\hline Vocational secondary & 3.0 & 4.4 & 5.1 & 3.2 & 3.0 & 5.4 \\
\hline Professional secondary/Incomplete higher & 2.3 & 4.7 & 4.4 & 4.9 & 3.8 & 3.2 \\
\hline University & 2.5 & 4.4 & 1.7 & 3.0 & 2.2 & 3.4 \\
\hline \multicolumn{7}{|l|}{ Job tenure } \\
\hline$<1$ Year & 2.8 & - & 4.2 & 3.4 & 3.3 & 5.6 \\
\hline 1Year & 3.6 & 5.3 & 5.1 & 4.8 & 4.1 & 4.5 \\
\hline 2-5Years & 3.7 & 7.0 & 3.9 & 4.7 & 2.2 & 3.7 \\
\hline 6-10 Years & 2.5 & 6.4 & 4.3 & 4.8 & 5.4 & 3.3 \\
\hline 11 Years + & 2.0 & 3.4 & 3.7 & 4.6 & 3.1 & 4.8 \\
\hline \multicolumn{7}{|l|}{ Occupation } \\
\hline Legislators, Senior Managers, Officials & 1.4 & 3.0 & 3.7 & 2.0 & 5.6 & 2.0 \\
\hline Professionals & 1.9 & 2.9 & 2.3 & 3.1 & 1.5 & 2.3 \\
\hline Technicians and Associate Professionals & 1.9 & 5.6 & 2.1 & 4.0 & 2.5 & 2.5 \\
\hline Clerks & 2.2 & 7.5 & 5.7 & 4.2 & 4.3 & 6.1 \\
\hline Service Workers and Market Workers & 3.7 & 5.7 & 6.8 & 5.2 & 1.4 & 4.7 \\
\hline Skilled Agricultural and Fishery Workers & - & 6.4 & 5.7 & 11.0 & 1.5 & 7.9 \\
\hline Craft and Related Trades & 4.5 & 5.6 & 5.2 & 5.0 & 3.9 & 6.0 \\
\hline Plant and Machine Operators and Assemblers & 1.5 & 4.1 & 2.7 & 4.5 & 4.8 & 6.7 \\
\hline Elementary (Unskilled) Occupations & 2.3 & 5.1 & 2.8 & 5.8 & 3.4 & 5.1 \\
\hline \multicolumn{7}{|l|}{ Industry } \\
\hline Agriculture, hunting and forestry & 1.2 & 3.0 & 3.1 & 7.8 & 4.0 & 4.2 \\
\hline Manufacturing and mining & 3.4 & 5.2 & 4.6 & 5.4 & 4.6 & 6.5 \\
\hline Electricity, gas and water supply & 3.1 & 2.5 & - & 0.8 & 1.6 & 4.1 \\
\hline Construction & 3.6 & 11.0 & 6.7 & 6.0 & 3.6 & 6.5 \\
\hline Wholesale and retail trade; hotels & 5.2 & 10.1 & 7.7 & 6.5 & 4.3 & 5.7 \\
\hline Transport, storage and communication & 0.7 & 5.1 & 3.7 & 1.9 & 2.3 & 4.9 \\
\hline Financial intermediation, real estate & 5.1 & 8.9 & 4.0 & 2.6 & 6.4 & 5.8 \\
\hline Public Administration and defense & 3.2 & 2.4 & 2.6 & 4.9 & 4.9 & 2.3 \\
\hline Education, health and social work & 1.3 & 1.3 & 1.6 & 1.4 & 1.2 & 0.9 \\
\hline Social and personal service activities & 4.3 & 5.3 & 6.4 & 1.5 & 4.4 & 2.5 \\
\hline Other activities & - & 6.3 & 3.3 & 3.3 & - & 3.3 \\
\hline \multicolumn{7}{|l|}{ Type of enterprise/organization } \\
\hline State & 2.6 & 4.4 & 3.7 & 4.7 & 3.6 & 4.7 \\
\hline Cooperative & 7.3 & 13.5 & 6.7 & 1.9 & 2.0 & - \\
\hline Newly established enterprise & - & 8.6 & 6.0 & 6.8 & 4.1 & 5.2 \\
\hline
\end{tabular}




\begin{tabular}{lllllll}
\hline Privatized enterprise & 4.9 & 5.5 & 4.2 & 3.6 & 3.4 & 4.2 \\
Region & & & & & & \\
West & 1.1 & 2.6 & 1.4 & 2.4 & 1.8 & 1.4 \\
Kyiv City & 2.6 & 5.3 & 3.4 & 3.0 & 5.5 & 3.4 \\
Center \& North & 0.8 & 3.8 & 2.2 & 2.8 & 2.4 & 4.2 \\
East & 1.3 & 3.1 & 2.8 & 3.2 & 2.5 & 3.3 \\
South & 1.6 & 3.6 & 4.9 & 3.9 & 2.4 & 3.6 \\
Total & 2.7 & 4.8 & 4.0 & 4.5 & 3.4 & 4.3 \\
\hline
\end{tabular}

Source: ULMS.

Table A3. Discrete Piecewise Proportional Hazard Estimates of Jobless Spell Excluding Movements into Retirement (No Unobserved Heterogeneity)

\begin{tabular}{|c|c|c|c|c|c|c|}
\hline & \multicolumn{3}{|c|}{ 1992-97 } & \multicolumn{3}{|c|}{ 1998-2002 } \\
\hline Displaced & $\begin{array}{l}\text { Total } \\
-0.114 \\
(0.064)\end{array}$ & Displaced & Quit & $\begin{array}{l}\text { Total } \\
-0.182 \\
(0.058) *\end{array}$ & Displaced & Quit \\
\hline \multicolumn{7}{|l|}{ Individual } \\
\hline Age 16-24 & $\begin{array}{l}0.422 \\
(0.127)^{*}\end{array}$ & $\begin{array}{l}0.471 \\
(0.250)\end{array}$ & $\begin{array}{l}0.497 \\
(0.154)^{*}\end{array}$ & $\begin{array}{l}0.303 \\
(0.097)^{*}\end{array}$ & $\begin{array}{l}0.463 \\
(0.189)^{*}\end{array}$ & $\begin{array}{l}0.237 \\
(0.115)^{*}\end{array}$ \\
\hline Age $25-34$ & $\begin{array}{l}0.427 \\
(0.103)^{*}\end{array}$ & $\begin{array}{l}0.183 \\
(0.176)\end{array}$ & $\begin{array}{l}0.519 \\
(0.133)^{*}\end{array}$ & $\begin{array}{l}0.274 \\
(0.087) *\end{array}$ & $\begin{array}{l}0.346 \\
(0.152)^{*}\end{array}$ & $\begin{array}{l}0.260 \\
(0.108) *\end{array}$ \\
\hline Age $35-44$ & $\begin{array}{l}0.405 \\
(0.098) *\end{array}$ & $\begin{array}{l}0.118 \\
(0.158)\end{array}$ & $\begin{array}{l}0.591 \\
(0.131)^{*}\end{array}$ & $\begin{array}{l}0.248 \\
(0.083)^{*}\end{array}$ & $\begin{array}{l}0.291 \\
(0.131)^{*}\end{array}$ & $\begin{array}{l}0.221 \\
(0.109)^{*}\end{array}$ \\
\hline Female & $\begin{array}{l}-0.573 \\
(0.105)^{*}\end{array}$ & $\begin{array}{l}-0.220 \\
(0.191)\end{array}$ & $\begin{array}{l}-0.710 \\
(0.130)^{*}\end{array}$ & $\begin{array}{l}-0.732 \\
(0.084)^{*}\end{array}$ & $\begin{array}{l}-0.746 \\
(0.152)^{*}\end{array}$ & $\begin{array}{l}-0.702 \\
(0.102)^{*}\end{array}$ \\
\hline Kids & $\begin{array}{l}0.127 \\
(0.099)\end{array}$ & $\begin{array}{l}0.491 \\
(0.186)^{*}\end{array}$ & $\begin{array}{l}-0.030 \\
(0.122)\end{array}$ & $\begin{array}{l}0.092 \\
(0.083)\end{array}$ & $\begin{array}{l}-0.025 \\
(0.149)\end{array}$ & $\begin{array}{l}0.150 \\
(0.101)\end{array}$ \\
\hline Female*Kids & $\begin{array}{l}0.179 \\
(0.127)\end{array}$ & $\begin{array}{l}-0.026 \\
(0.227)\end{array}$ & $\begin{array}{l}0.240 \\
(0.156)\end{array}$ & $\begin{array}{l}0.175 \\
(0.108)\end{array}$ & $\begin{array}{l}0.318 \\
(0.195)\end{array}$ & $\begin{array}{l}0.051 \\
(0.132)\end{array}$ \\
\hline Married & $\begin{array}{l}-0.081 \\
(0.071)\end{array}$ & $\begin{array}{l}-0.411 \\
(0.123)^{*}\end{array}$ & $\begin{array}{l}0.089 \\
(0.091)\end{array}$ & $\begin{array}{l}-0.053 \\
(0.062)\end{array}$ & $\begin{array}{l}-0.014 \\
(0.114)\end{array}$ & $\begin{array}{l}-0.054 \\
(0.074)\end{array}$ \\
\hline Ukrainian & $\begin{array}{l}-0.084 \\
(0.070)\end{array}$ & $\begin{array}{l}-0.204 \\
(0.134)\end{array}$ & $\begin{array}{l}-0.033 \\
(0.084)\end{array}$ & $\begin{array}{l}0.050 \\
(0.063)\end{array}$ & $\begin{array}{l}0.214 \\
(0.113)\end{array}$ & $\begin{array}{l}-0.034 \\
(0.077)\end{array}$ \\
\hline Education & & & & & & \\
\hline $\begin{array}{l}\text { Professional } \\
\text { secondary }\end{array}$ & $\begin{array}{l}0.055 \\
(0.073)\end{array}$ & $\begin{array}{l}0.119 \\
(0.133)\end{array}$ & $\begin{array}{l}0.063 \\
(0.090)\end{array}$ & $\begin{array}{l}0.172 \\
(0.066) *\end{array}$ & $\begin{array}{l}0.197 \\
(0.112)\end{array}$ & $\begin{array}{l}0.169 \\
(0.082)^{*}\end{array}$ \\
\hline Graduate & $\begin{array}{l}0.417 \\
(0.083) *\end{array}$ & $\begin{array}{l}0.145 \\
(0.151)\end{array}$ & $\begin{array}{l}0.560 \\
(0.103)^{*}\end{array}$ & $\begin{array}{l}0.469 \\
(0.072) *\end{array}$ & $\begin{array}{l}0.488 \\
(0.137) *\end{array}$ & $\begin{array}{l}0.456 \\
(0.086) *\end{array}$ \\
\hline Works Land Plot & $\begin{array}{l}-0.049 \\
(0.062)\end{array}$ & $\begin{array}{l}-0.097 \\
(0.111)\end{array}$ & $\begin{array}{l}-0.038 \\
(0.076)\end{array}$ & $\begin{array}{l}-0.042 \\
(0.057)\end{array}$ & $\begin{array}{l}0.029 \\
(0.104)\end{array}$ & $\begin{array}{l}-0.066 \\
(0.069)\end{array}$ \\
\hline Job & & & & & & \\
\hline Tenure $<1$ year & $\begin{array}{l}-0.471 \\
(0.201)^{*}\end{array}$ & $\begin{array}{l}-1.013 \\
(0.464)^{*}\end{array}$ & $\begin{array}{l}-0.357 \\
(0.228)\end{array}$ & $\begin{array}{l}-0.036 \\
(0.101)\end{array}$ & $\begin{array}{l}-0.077 \\
(0.184)\end{array}$ & $\begin{array}{l}-0.004 \\
(0.123)\end{array}$ \\
\hline Tenure $1-5$ years & $\begin{array}{l}-0.108 \\
(0.086)\end{array}$ & $\begin{array}{l}0.138 \\
(0.159)\end{array}$ & $\begin{array}{l}-0.178 \\
(0.104)\end{array}$ & $\begin{array}{l}0.070 \\
(0.083)\end{array}$ & $\begin{array}{l}0.012 \\
(0.144)\end{array}$ & $\begin{array}{l}0.076 \\
(0.103)\end{array}$ \\
\hline Tenure $5-10$ years & $\begin{array}{l}0.052 \\
(0.077)\end{array}$ & $\begin{array}{l}0.308 \\
(0.131)^{*}\end{array}$ & $\begin{array}{l}-0.032 \\
(0.097)\end{array}$ & $\begin{array}{l}0.147 \\
(0.085)\end{array}$ & $\begin{array}{l}0.182 \\
(0.143)\end{array}$ & $\begin{array}{l}0.125 \\
(0.108)\end{array}$ \\
\hline Firm Size 1000+ & $\begin{array}{l}-0.012 \\
(0.070)\end{array}$ & $\begin{array}{l}0.065 \\
(0.124)\end{array}$ & $\begin{array}{l}-0.044 \\
(0.088)\end{array}$ & $\begin{array}{l}-0.131 \\
(0.081)\end{array}$ & $\begin{array}{l}-0.068 \\
(0.142)\end{array}$ & $\begin{array}{l}-0.163 \\
(0.101)\end{array}$ \\
\hline Industry & & & & & & \\
\hline
\end{tabular}




\begin{tabular}{|c|c|c|c|c|c|c|}
\hline Manufacturing & $\begin{array}{l}0.936 \\
(0.089)^{*}\end{array}$ & $\begin{array}{l}1.007 \\
(0.158)^{*}\end{array}$ & $\begin{array}{l}0.976 \\
(0.113)^{*}\end{array}$ & $\begin{array}{l}0.470 \\
(0.075)^{*}\end{array}$ & $\begin{array}{l}0.538 \\
(0.133)^{*}\end{array}$ & $\begin{array}{l}0.470 \\
(0.093)^{*}\end{array}$ \\
\hline Retail & $\begin{array}{l}0.839 \\
(0.094)^{*}\end{array}$ & $\begin{array}{l}0.977 \\
(0.186)^{*}\end{array}$ & $\begin{array}{l}0.786 \\
(0.113)^{*}\end{array}$ & $\begin{array}{l}0.453 \\
(0.084)^{*}\end{array}$ & $\begin{array}{l}0.654 \\
(0.144)^{*}\end{array}$ & $\begin{array}{l}0.339 \\
(0.105)^{*}\end{array}$ \\
\hline Transport & $\begin{array}{l}0.829 \\
(0.133)^{*}\end{array}$ & $\begin{array}{l}0.915 \\
(0.237)^{*}\end{array}$ & $\begin{array}{l}0.777 \\
(0.167)^{*}\end{array}$ & $\begin{array}{l}0.418 \\
(0.130)^{*}\end{array}$ & $\begin{array}{l}0.553 \\
(0.212)^{*}\end{array}$ & $\begin{array}{l}0.325 \\
(0.168)\end{array}$ \\
\hline Finance & $\begin{array}{l}0.807 \\
(0.205)^{*}\end{array}$ & $\begin{array}{l}1.750 \\
(0.387)^{*}\end{array}$ & $\begin{array}{l}0.478 \\
(0.247)\end{array}$ & $\begin{array}{l}0.241 \\
(0.185)\end{array}$ & $\begin{array}{l}0.325 \\
(0.335)\end{array}$ & $\begin{array}{l}0.174 \\
(0.224)\end{array}$ \\
\hline Education\&Health & $\begin{array}{l}1.104 \\
(0.098) *\end{array}$ & $\begin{array}{l}1.266 \\
(0.169) *\end{array}$ & $\begin{array}{l}1.026 \\
(0.123)^{*}\end{array}$ & $\begin{array}{l}0.506 \\
(0.095)^{*}\end{array}$ & $\begin{array}{l}0.500 \\
(0.209) *\end{array}$ & $\begin{array}{l}0.498 \\
(0.109)^{*}\end{array}$ \\
\hline \multicolumn{7}{|l|}{ Ownership } \\
\hline New Private & $\begin{array}{l}0.117 \\
(0.204)\end{array}$ & $\begin{array}{l}0.455 \\
(0.390)\end{array}$ & $\begin{array}{l}0.037 \\
(0.246)\end{array}$ & $\begin{array}{l}0.055 \\
(0.080)\end{array}$ & $\begin{array}{l}-0.006 \\
(0.145)\end{array}$ & $\begin{array}{l}0.085 \\
(0.098)\end{array}$ \\
\hline Privatised/Foreign & $\begin{array}{l}-0.402 \\
(0.213)\end{array}$ & $\begin{array}{l}-0.724 \\
(0.473)\end{array}$ & $\begin{array}{l}-0.370 \\
(0.242)\end{array}$ & $\begin{array}{l}-0.059 \\
(0.096)\end{array}$ & $\begin{array}{l}-0.033 \\
(0.193)\end{array}$ & $\begin{array}{l}-0.068 \\
(0.112)\end{array}$ \\
\hline \multicolumn{7}{|l|}{ Region } \\
\hline Central/North & $\begin{array}{l}-0.029 \\
(0.090)\end{array}$ & $\begin{array}{l}-0.012 \\
(0.150)\end{array}$ & $\begin{array}{l}-0.045 \\
(0.116)\end{array}$ & $\begin{array}{l}-0.124 \\
(0.078)\end{array}$ & $\begin{array}{l}-0.390 \\
(0.140)^{*}\end{array}$ & $\begin{array}{l}0.008 \\
(0.095)\end{array}$ \\
\hline Kyiv & $\begin{array}{l}0.004 \\
(0.116)\end{array}$ & $\begin{array}{l}-0.362 \\
(0.226)\end{array}$ & $\begin{array}{l}0.068 \\
(0.137)\end{array}$ & $\begin{array}{l}0.272 \\
(0.099)^{*}\end{array}$ & $\begin{array}{l}0.315 \\
(0.188)\end{array}$ & $\begin{array}{l}0.250 \\
(0.119)^{*}\end{array}$ \\
\hline South & $\begin{array}{l}0.066 \\
(0.093)\end{array}$ & $\begin{array}{l}-0.008 \\
(0.172)\end{array}$ & $\begin{array}{l}0.095 \\
(0.114)\end{array}$ & $\begin{array}{l}0.040 \\
(0.084)\end{array}$ & $\begin{array}{l}0.083 \\
(0.141)\end{array}$ & $\begin{array}{l}-0.026 \\
(0.107)\end{array}$ \\
\hline West & $\begin{array}{l}-0.126 \\
(0.091)\end{array}$ & $\begin{array}{l}-0.223 \\
(0.151)\end{array}$ & $\begin{array}{l}-0.063 \\
(0.118)\end{array}$ & $\begin{array}{l}-0.230 \\
(0.085)^{*}\end{array}$ & $\begin{array}{l}-0.259 \\
(0.151)\end{array}$ & $\begin{array}{l}-0.230 \\
(0.104)^{*}\end{array}$ \\
\hline \multicolumn{7}{|l|}{ Duration } \\
\hline$<1$ month & $\begin{array}{l}1.812 \\
(0.101)^{*}\end{array}$ & $\begin{array}{l}1.657 \\
(0.180)^{*}\end{array}$ & $\begin{array}{l}1.799 \\
(0.123)^{*}\end{array}$ & $\begin{array}{l}3.329 \\
(0.060)^{*}\end{array}$ & $\begin{array}{l}3.050 \\
(0.101)^{*}\end{array}$ & $\begin{array}{l}3.454 \\
(0.075)^{*}\end{array}$ \\
\hline $1-3$ months & $\begin{array}{l}2.551 \\
(0.064)^{*}\end{array}$ & $\begin{array}{l}2.390 \\
(0.114) *\end{array}$ & $\begin{array}{l}2.594 \\
(0.079)^{*}\end{array}$ & $\begin{array}{l}0.184 \\
(0.122)\end{array}$ & $\begin{array}{l}-0.020 \\
(0.211)\end{array}$ & $\begin{array}{l}0.285 \\
(0.150)\end{array}$ \\
\hline 3-6 months & $\begin{array}{l}0.391 \\
(0.151)^{*}\end{array}$ & $\begin{array}{l}0.795 \\
(0.212) *\end{array}$ & $\begin{array}{l}0.043 \\
(0.220)\end{array}$ & $\begin{array}{l}0.430 \\
(0.115)^{*}\end{array}$ & $\begin{array}{l}0.295 \\
(0.193)\end{array}$ & $\begin{array}{l}0.503 \\
(0.144)^{*}\end{array}$ \\
\hline Constant & $\begin{array}{l}-4.742 \\
(0.135)^{*}\end{array}$ & $\begin{array}{l}-4.854 \\
(0.236)^{*}\end{array}$ & $\begin{array}{l}-4.759 \\
(0.165)^{*}\end{array}$ & $\begin{array}{l}-4.199 \\
(0.124)^{*}\end{array}$ & $\begin{array}{l}-4.423 \\
(0.217)^{*}\end{array}$ & $\begin{array}{l}-4.182 \\
(0.152)^{*}\end{array}$ \\
\hline $\log \mathrm{L}$ & -4924 & -1676 & -3212 & -4408 & -1627 & -2761 \\
\hline
\end{tabular}

Source: ULMS Note: Standard errors are in brackets. * significant at $5 \%$ level

Table A4. Probit Estimates of After Displacement Wage Sample $\left(1^{\text {st }}\right.$ Stage Selection $)$

\begin{tabular}{|c|c|c|c|c|}
\hline & Wage Level & $\begin{array}{l}\text { Wage } \\
\text { Change }\end{array}$ & $\begin{array}{l}\text { Sample Mean } \\
\text { no returns }\end{array}$ & $\begin{array}{l}\text { Sample Mean } \\
\text { returns }\end{array}$ \\
\hline \multicolumn{5}{|l|}{ Individual } \\
\hline Age $16-24$ & $\begin{array}{c}0.077 \\
(0.193)\end{array}$ & $\begin{array}{l}0.001 \\
(0.196)\end{array}$ & 0.11 & 0.11 \\
\hline Age $25-34$ & $\begin{array}{l}0.330 \\
(0.136)^{*}\end{array}$ & $\begin{array}{l}0.331 \\
(0.141)^{*}\end{array}$ & 0.19 & 0.28 \\
\hline Age $35-44$ & $\begin{array}{l}0.287 \\
(0.117)^{*}\end{array}$ & $\begin{array}{l}0.252 \\
(0.118) *\end{array}$ & 0.32 & 0.36 \\
\hline Female & $\begin{array}{l}-0.123 \\
(0.102)\end{array}$ & $\begin{array}{l}-0.078 \\
(0.102)\end{array}$ & 0.54 & 0.51 \\
\hline Single & 0.083 & 0.098 & 0.20 & 0.23 \\
\hline
\end{tabular}




\begin{tabular}{|c|c|c|c|c|}
\hline & $(0.129)$ & $(0.131)$ & & \\
\hline Vocational higher & $\begin{array}{l}0.175 \\
(0.109)\end{array}$ & $\begin{array}{l}0.184 \\
(0.117)\end{array}$ & 0.22 & 0.25 \\
\hline Graduate & $\begin{array}{l}0.290 \\
(0.140)^{*}\end{array}$ & $\begin{array}{l}0.276 \\
(0.144)\end{array}$ & 0.12 & 0.17 \\
\hline \multicolumn{5}{|l|}{ Region } \\
\hline Centre \& North & $\begin{array}{l}-0.568 \\
(0.197)^{*}\end{array}$ & $\begin{array}{l}-0.471 \\
(0.200)^{*}\end{array}$ & 0.29 & 0.19 \\
\hline East & $\begin{array}{l}-0.088 \\
(0.185)\end{array}$ & $\begin{array}{l}-0.011 \\
(0.181)\end{array}$ & 0.27 & 0.40 \\
\hline South & $\begin{array}{l}-0.195 \\
(0.201)\end{array}$ & $\begin{array}{l}-0.078 \\
(0.204)\end{array}$ & 0.17 & 0.20 \\
\hline West & $\begin{array}{l}-0.783 \\
(0.211)^{*}\end{array}$ & $\begin{array}{l}-0.729 \\
(0.207)^{*}\end{array}$ & 0.21 & 0.09 \\
\hline \multicolumn{5}{|l|}{ Firm } \\
\hline Privatised & $\begin{array}{c}-0.168 \\
(0.187)\end{array}$ & $\begin{array}{l}-0.179 \\
(0.178)\end{array}$ & 0.06 & 0.07 \\
\hline New Private & $\begin{array}{l}-0.126 \\
(0.147)\end{array}$ & $\begin{array}{l}-0.064 \\
(0.148)\end{array}$ & 0.17 & 0.22 \\
\hline Foreign Owned & $\begin{array}{l}-0.473 \\
(0.397)\end{array}$ & $\begin{array}{l}-0.449 \\
(0.393)\end{array}$ & 0.02 & 0.02 \\
\hline Tenure $<1$ year & $\begin{array}{l}0.084 \\
(0.176)\end{array}$ & $\begin{array}{c}0.078 \\
(0.182)\end{array}$ & 0.11 & 0.11 \\
\hline Tenure $1-5$ years & $\begin{array}{l}0.469 \\
(0.141)^{*}\end{array}$ & $\begin{array}{l}0.399 \\
(0.143) *\end{array}$ & 0.25 & 0.39 \\
\hline Tenure $5-10$ years & $\begin{array}{l}0.137 \\
(0.137)\end{array}$ & $\begin{array}{l}0.130 \\
(0.139)\end{array}$ & 0.20 & 0.21 \\
\hline \multicolumn{5}{|l|}{ Industry } \\
\hline Agriculture & $\begin{array}{l}-0.456 \\
(0.172)^{*}\end{array}$ & $\begin{array}{l}-0.458 \\
(0.173)^{*}\end{array}$ & 0.12 & 0.10 \\
\hline Construction & $\begin{array}{l}0.020 \\
(0.181)\end{array}$ & $\begin{array}{l}0.033 \\
(0.183)\end{array}$ & 0.07 & 0.08 \\
\hline Retail & $\begin{array}{l}0.145 \\
(0.151)\end{array}$ & $\begin{array}{l}0.103 \\
(0.152)\end{array}$ & 0.14 & 0.23 \\
\hline Transport & $\begin{array}{c}0.010 \\
(0.192)\end{array}$ & $\begin{array}{c}0.025 \\
(0.189)\end{array}$ & 0.07 & 0.07 \\
\hline Finance & $\begin{array}{c}0.177 \\
(0.256)\end{array}$ & $\begin{array}{l}-0.017 \\
(0.310)\end{array}$ & 0.02 & 0.03 \\
\hline Public Service & $\begin{array}{l}-0.217 \\
(0.260)\end{array}$ & $\begin{array}{l}-0.296 \\
(0.278)\end{array}$ & 0.05 & 0.03 \\
\hline Education/Health & $\begin{array}{l}-0.185 \\
(0.218)\end{array}$ & $\begin{array}{l}-0.049 \\
(0.241)\end{array}$ & 0.08 & 0.06 \\
\hline Other Services & $\begin{array}{c}0.165 \\
(0.205)\end{array}$ & $\begin{array}{c}0.059 \\
(0.252)\end{array}$ & 0.06 & 0.07 \\
\hline Firm_size 100-999 & $\begin{array}{l}0.253 \\
(0.131)\end{array}$ & $\begin{array}{l}0.219 \\
(0.131)\end{array}$ & 0.28 & 0.29 \\
\hline Firm Size 1000+ & $\begin{array}{l}0.218 \\
(0.166)\end{array}$ & $\begin{array}{l}0.203 \\
(0.172)\end{array}$ & 0.15 & 0.17 \\
\hline Ethnic Minority & $\begin{array}{l}-0.051 \\
(0.085)\end{array}$ & $\begin{array}{l}-0.132 \\
(0.088)\end{array}$ & 0.21 & 0.29 \\
\hline Children $<6$ years & 0.033 & 0.053 & 0.12 & 0.15 \\
\hline
\end{tabular}




\begin{tabular}{lllll}
\hline \multirow{2}{*}{ Female*children<6 } & $(0.136)$ & $(0.173)$ & & \\
& -0.201 & -0.352 & 0.06 & 0.06 \\
Divorced/widowed & $(0.188)$ & $(0.184)$ & & 0.04 \\
& 0.346 & 0.327 & 0.03 & 0.44 \\
Farms a plot of land & $(0.186)$ & $(0.220)$ & & \\
& 0.089 & -0.041 & 0.59 & 4.81 \\
Log(old_wage) & $(0.078)$ & $(0.094)$ & & \\
Constant & & & 4.48 & \\
& -1.046 & -1.000 & & \\
\hline
\end{tabular}

Notes Standard errors in brackets. * statistically significant at the 5\% level. Sample of non-returners is 619. 